\title{
MEDENİ HUKUK AÇISINDAN ÖLÜM ANININ BELİRLENMESİ VE CESET ÜZERİNDEKİ HAKKA ILIŞKIN BAZI DÜŞÜNCELER
}

\author{
Yrd. Doç. Dr. Çă̆lar ÖZEL*
}

\section{I- GIRİ̧}

\section{A- Genel Olarak}

Günümüzde bütün hızıyla yaşanan tıp ve biyoloji alanındaki yeni gelişmeler, yaşamın başlangıcı ve sonuna ilişkin geleneksel görüşlerin değişmesine yol açmakta, hukuk, tıp, ahlak ve din adamalarını farklı boyutlarda yeni sorunlarla karşı karşıya getirmektedir.'

Hukuk kuralları, kişilerin toplu halde yaşamını düzenleyen, hak ve yükümlülükler öngören toplumsal düzen kurallarıdır. ${ }^{2}$ Özel hukukun bir bölümü olarak kişiler hukuku ise insan ve insan topluluklarının hukuk düzeni içindeki yerinin ne oldugu sorusuyla ilgilenir. Hukuk düzeni içinde, insana ${ }^{3}$, yani gerçek kişiye ilişkin olarak bu soruya verilecek yant, baskm olarak kabul edilen ahlaksal düşüncelere bağlıdır. Ahlaksal açıdan insan olarak kendisine karşı sorumluluğu taşıdığını gösteren kişi, aynı zamanda hukuk toplumunun sorumlu bir üyesi, hakların öznesi olarak görülür. Buna karşılık hiç bir zaman bir hakkın konusu ya da amaca ulaşmak açısından bir

\footnotetext{
• H.U. İİB.F. Kamu Yönetimi Bölümü Beytepe/Ankara

' Özsunay (Hayat), s. 4. Öğretide yaşamın başlangıcı ve sonuna ilişkin olarak "dölünü sürdürme (üreme) hakkı". "benzersiz olma hakkı". "kimljğini bilme hakkı". "müdahale edilmemiş bir genctik köke sahip olma hakkı", "farklı olma hakkı". biyolojik kökenini bilme hakkı", "hastalığıı öğrenme hakkı" "ölme hakkı", "insan onuruyla ölme hakkı" gibi yeni hak kategorilerinin ortaya çıktığından söz edjlmektedir. Bu konuda bak. Özsunay (Hayat), s, 4 vd. B Bilge, 12; Umar, 12.

${ }^{3}$ Insanın topluluk içinde ve buna bağlı olarak hukukta aldı̌̆ı yer, Roma'nın gelişini içinde epeyce değişmiştir. Eski Roma dönemi insaaı henüz bircy olarak görmemekte, aksine içinde buiunduğu birliklerin bir üyesi olarak görmekteydi. Bunlar, özel hukuk ilişkileri açısından en büyük birlik oluşturan devletle, en küçük birlik olan ailedir (Kaser, 60).
} 
araç olarak görülemez. ${ }^{4}$ Hak ve yükümlülüklerin öznesi olma iktidar ise hak ehliyetidir. $\mathrm{Bu}$ çerçevede insan, hukuk düzeni açısından kişidir, yani hakların ve yükümlülüklerin sahibidir. ${ }^{6}$ Ancak hak ehliyetine sahip varlık olarak sadece insan kişi sayılmaz. Aynı zamanda hukuk düzeni kişi birliklerine ve mal topluluklarına (tüzel kişiler) da hak ehliyeti tanımış, yani onları da kişi saymıştır?

Konumuz, gerçek kişiliğin sona ermesine neden olan en doğal olayla, yani ölüm ile doğrudan ilgilidir. ${ }^{8}$ Bu çerçevede açıklamalarımızı, insanın ölümii açısından yapacağ̀ı.

Ölüm olayının hukuksal ilişkiler ve toplumsal yaşamdaki önemi yadsınamazsa da, ölüm anının belirlenmesi Medeni Hukık açısından ayrı bir önemi hatizdir. Gerçekten, özellikle miras hukukunda kimin önce öldüğŭnün

\footnotetext{
${ }^{+}$Merı,32I: Bilge. 4. Çăgdaş düşünce bu olmasına karş̧lık, farkh hukuk düzenlerinde aynı esasın gerçekleşliğinden söz edilemez. Bak. Dural/Öğüz(Durab), 6: Güriz, 112: Hatemi, 2: Akipok/Akıntürk, 10 ; Zevkliler/Acabey/Gökyayla, 229. (Bu yazarlara göre baskasısın kişiliğ̀ üzerinde hak sithibi olunamamakla birlikte yaşam alanları ve bazı ilişkileri üzerinde hak sahibj olmak mümküindür (Bak. Zevkliler/Acabey/Gökyayla ,120). "Geleneksel hakiar şemasında velayetin ve vesayetin başkasının şahsi üzerinde egemenlik hakkı olarak sumulması talihsizliktir. Kölclik tasfiye edileli beri insan üstünde hukuki egemenlik varsayılamaz." Hatemi/Serozan/Arpaci, 9. Karş. Bilge, 217.

${ }^{5}$ Öztan. 39: Dural/Öğ̈̈z(Dural). 39; Zevkłiler/Acabey/Gökyayla. 229; Merz. 321. Medenı Kanunun 8. maddesinin kenar başlığı. kaynak Jsviçre Medeni Kanunun (ZGB) bu maddeyi karşlayan 11. maddesinin Fransızca metrine uygun olarak "Medeni haklardan yararlanına" (jeouissance de droit civils) demektedir. Buna karşılık almanea metinde geçen "Rechtsfähigkeit" anlarmondaki hak chliyeti deyimi, bugün türk hukukunda da baskın olarak kullanılan terimslir. Bak. Dural/Öğizz(Dural)/Öğüz, 39;Oğuzman/Seliçi/Oktay. 29: Tekinay. 201: Ötan. 39: Hak ehliyeti (Rechtsfähigkeit) kavramı çağdaş hukuklara Roma kaynaklarından aktarılmış olmasına karşılık, Roma döneminde romalılar tarafindå henüy formüle edilmemisti (Kaser, 63). Ayrıca bak. Gürkan, 44 vd., 48.

"Kişi ve kişilik hukuki kavramlardır (Oğuzman/Seliçi/Oktay, 2). Bu sözcükler genèl dilde ise daha çok doğal terimlerdir. Bunlar en genel ve en önctnit insansal olgularil ozzüuliur. insan ruhunun felsefi doğası anlamında şöyle tanımlanabilir: Kiși (Person) ruhsal varlı̆̆ın

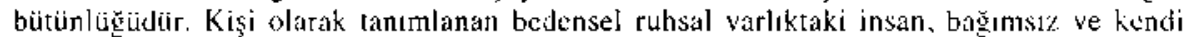
ıçinde bütünsel (bircy olarak) olarak ortaya çıkar. Cins isim olan kişi katvramına bağlı olarak kişilik ise bircy olarak insandır; yani, doğası gereği birey olan ve csscizliği jçinde chliyetlerinitı bütünlüğui ile ve kendisini ortaya çıáran eylemleriyle bireyi oluşturur. (Merz, 145a,I46a). Ayrica hak. Gürkan, 41 vd.

3 Öztan. 7-8; Dural/Öğüz(Dural), 6; Tekinay, 201; Akipek/Akıntürk, 3: Zevkliler/Acabey/Gökyayla, 209; Jäggi. 148a.

* Bu çerçevede gerçck kişilerin kişiliğinin ölüme eş değer varsayımsal olarak sona crmesi konularına değinilmeyecektir. Bu konularda bkz. Zevkliler/Acabey/Gökyayla, 564 vd.; Tekinay. 211 vd. :Akipek/Akıntürk, 19 vd; Dural/Öğüz(Dural), 27 vd. ; Ötan, 29 vd. Oğuzman/Seliçi/Oktay.18 vd. Ayrıca eski hukuklarda varolan, ancak günümüz. hukuklarında yer almayan bir kurum olan yaşamakta olan bir insanın bazı ncdenlerle (bir suçtan mahkum olma, din ad:amı olma gibi), hukuksal olarak kişi olma niteliğini kaybetmesi hallesmi (medeni ölïıı. manastır ölümü) de konumuzun dışında tutuyoruz (bak. Velidedeoğ̀lu. 8: Köprúlı. 240. dn. 2; Grossen. 303; Akipek/Akıntürk. 1 1; Dural/Öğüz(Dural). 20; Öztan. 21 ).
} 
belirlenmesi açısından, bazan dakikalar hatta saniyeler terekenin geleceği hakkında verilecek kararın deģişmesine yol açacaktır." Bunun yanısıra insan bedeninin "ceset" olarak nitelendirilmesi anından itibaren, hukuk düzeni içinde ceset üzerinde yapılacak tasarruflar söz konusu olabilecektir (organ ya da doku alınabilmesi, otopsi gibi) ${ }^{10}$. Bu çerçevede insan bedeninin ne zaman cansız beden (ceset) sayılacağı hususu üzerinde durmak zorunluluğu doğmaktadır. Tıp bilimi açısından bu hususta günümüzde baskın olan dïşüncenin "beyinsel ölüm" anlayışı olduğu iddia edilmektedir." Bu konulara aşağıda değinilecektir. ${ }^{12}$ Ancak yaşamın sona ermesi, öncelikle, başlamış bir yaşamın varlığını gerektirdiği için, aşağıda öncelikle doğuma ilişkin genel bilgilerin verilmesi ve daha sonra ölümle ilgili açılamalara geçilmesi zorunluluğu doğmaktadır.

\section{B- Doğum}

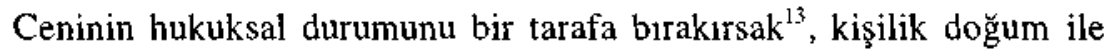
ölüm arasındaki zaman parçasında söz konusu olur. Bu anlamda doğum ile ölüm arasında yer alan kimilerine göre çok kısa kimilerine göre çok uzun zaman parçası olan süre insanın yaşamıdır ${ }^{14}$. Bu anlamda ölümün tanımlanması ya da başka bir deyişle ölïmün ne zaman gerçekleştiğinin belirlenmesi için bunun başlangıcının da yani doğumun da hukuksal açıdan belirlenmesi kaçınımazdır.

\footnotetext{
"Bu konuda özellikle Köprülü tarafından formüle edilen şu örneğe dikkat çekmek istiyoruz." ... karı kocanın tek çocukları dünyaya geldikten bir kaç dakika sonra, önce karı, ondan kısa bir süre sonra da çocuk ölürse , koca karısının (karısırın ölümü sonucu 1/4 kendi payı), çocuğun ölümü üzerine de, onın anasından miras hakkı olarak aldığı $3 / 4$ payın, bu kere kendisine verilmesi sonucu mirasın tamamına sahip olacakur. Çocuğun ölümünden sonra, ana, kalbine yapılan masaj yolu veya elektroşok ile kısa bir süre için hayata döner (avdet eder) ve fakat çocuğun ölümünden sonra da ölürse, çocuk ona (anasına) mirasçı olamıyacă̆ için koca, birlikte miraş̧ı bulunduğu zümreye göre , karısının mirasının tamamına değil. ancak bir bölümüne hak kazanacaktır. Başka bir deyişle, mirasın diğer bölüimünü ölen karısının miraş̧ıları alacaktır." (Köprülü, 243'den naklen). Ayrıca bak. Egger, Art. 31, N. 8, ; Öztan, s. 26. Karş. Arpact, 7, dn. 9'a ait metin.

"10 Bak. aşa. III D.

"Bak. Öztan, 22 ; Zevkliler/Acabey/Gökyayla, 557. Karş.Bilgin, 14 vd; Müller, s.465. Aksi fikirde: Dural/Öğgizz(Dural), 21; Arpaci, (184).

${ }^{12}$ Bak, aşa.II A1.

${ }^{13}$ Bu konuda bak.: Egger, Art.31, N.7 vd. ; Merz. 332 vd.;Zevkliler/Acabey/Gökyayla. 220 vd.; Öztan, 13 vd.; Dural/Öğüz(Dural). 17 vd.; Özsunay, 20; Köprülï, 233; Akipek/Akıntürk, 15 vd.; Arpacı, 7 vd.; Ataay, 42; Tekinay. 207 vd. Ayrıca embriyonun ve ceninin hukuksal durumu ile "gebeliğin sona erdirilmesi hakkı" açısından ortaya çıkan güncel sorunlarla ilgili olarak bak. Ozsunay (Hayat), s. 9 vd.

${ }^{14}$ Karş. Velidedeoğlu, 10.
} 
MK mo. 28 gereğince kişilik tann ve săg doğunla balşlar. "' Ancak

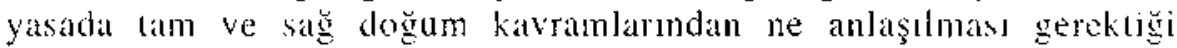
konustonda hir açıklık yoktur. Bunun açıklaması öğretj ve uyg̨ulama tarafmand gerçekleştirilecektir. ${ }^{\text {tht }}$

Tarttşmalı olmakla birlikte tam doğumun gerçekleşmiş salyılması için . çocuğ̆un ana karnından ayrılmış ve bağımsız bir varlık kaıanmış olması yeterlidir" ${ }^{17}$. Buna karşlık göbek bağının kesilmiş olmas ${ }_{1}{ }^{1 \times}$ doğgumun normal ya da sezeryanla olmast ${ }^{10}$ ya da çocuk eşinin (son, plesanta) ana bedeninden ayrilmass gerekmez $z^{2 !}$.

Kişiłiğin başlamış sayılabilmesi için gerekli sağ doğum koşulunun ne zaman gerçekteştiğinin belirtenmesi ise tıp biliminin işidir. Tıp bilimi açısından yaşam belirtisi bulunan durumlarda (nefes almas $1^{2-2}$, kalbinin atması, göbck bağ çocuğun, hukuken de săğ doğduğ kunu kabul etmek gerekir." Bu anlanda

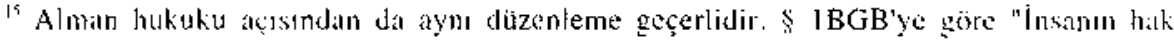

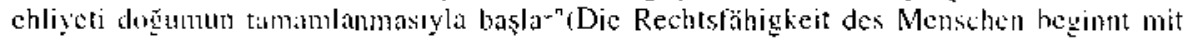
der vollendung der (seburt).

"20 ZevhliteríAcabey/Gäkyaylá. 215.

l'Egger. 338: Zevkliler/Acabey/Gokyayla. 215; OAtan, 12: Egegr, 338;

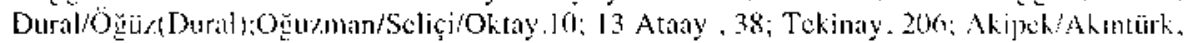
13 : Mer\% 32): Wolto Nalujoks. I8.

is Velidedeoglte. 10: Zevkliter/Acibey/Gökyayla. 215; Öztan, I2: Loger. 33s,

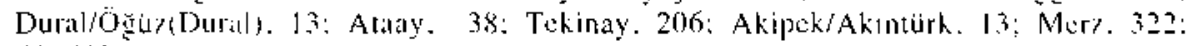
Wollowajess. Is

${ }^{14}$ Dural/(O)izaD Dur:t), 1,3: Zovklilcr/Acabcy/Gökyayla, 215.

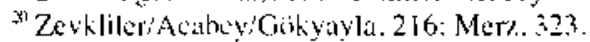

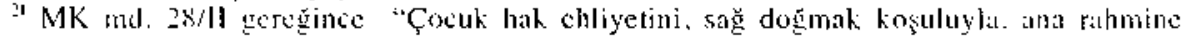

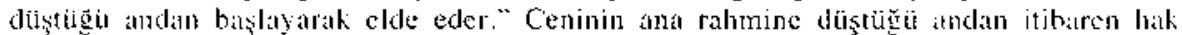

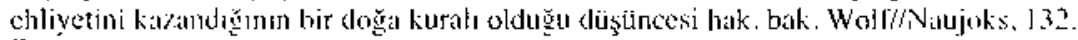

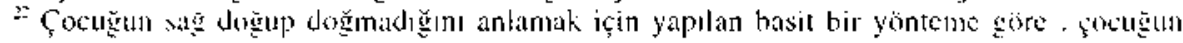

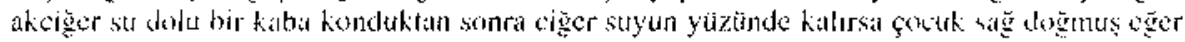

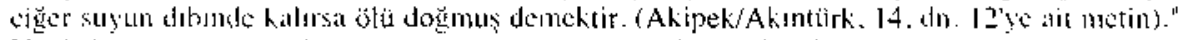

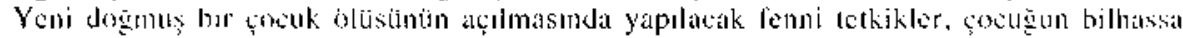

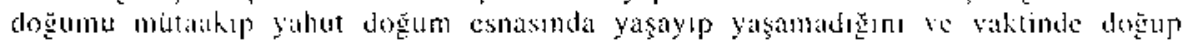

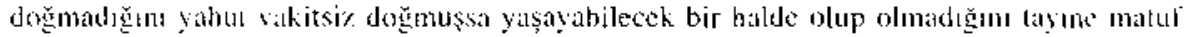
olur. " (CML:K ind. 82 )

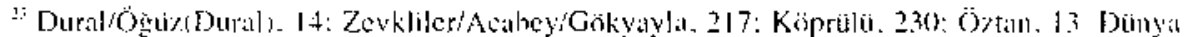

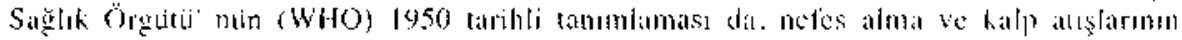

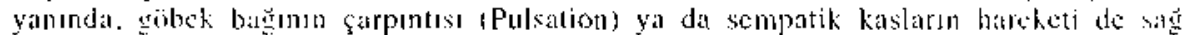
doğumut heirtileri alarak girüimüsür (Bak. Mer\%. 329-330: Wolj/Nalujohs. 2l). Mer\%e gore

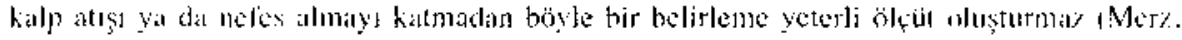
$330)$
} 
çocuğun bir an dahi olsa yaşaması yeterlidir ${ }^{24}$. Medeni Kanun md. 27 anlamında kişiliğin başlaması için başka koşul aranmaz.

\section{II- ÖLÜMÜN TANIMI}

\section{A- Genel Olarak}

Ölüm ve ölme olguları her zaman din adamı, hekim, hukukçu ve sıradan insanın ilgi ve dikkatini çeken, özellikle de organ ve doku alınması açısından büyük önem taşıyan ölçütlerin söz konusu olduğu "yaşamın gerçę่̧i" olarak ortaya çıkar. ${ }^{26}$ Ölümiu saptama yöntemlerini açığa çıkartma görevinin tip bilimine ait olduğ kuşku götürmez. Ancak ölüm olayının hukuksal düzenlemeye tâbi tutulması da kaçınılmazdır. Bu çerçeveden olarak kişilik haklarımın belirlenmesi açısından öliumle yaşam arasındaki sınırın saptanmasına hukukun yabancı kalması düşünuilemez. ${ }^{27}$ Doğal ve biyolojik bir olgu olan ölüme, hukuk tarafından da bazı sonuçlar bağlanmıştır. Ölümle birlikte kişilik sona erer (MK. md.28) ${ }^{28}$ Bunun yanısıra ölüme bağlı bazı hakların doğumu için, bu haklara sahip olacak kişilerin, kişinin ölüimü anında sağ olması gereklidir (MK. md.580, 581). Bunun gibi, özellikle vücutta tek olan ve kişinin yaşamının bunlarm varlığına bağlı organlarının alınması, ancak insanın ölmüş sayılmasına bağlıdır. ${ }^{29} \mathrm{Bu}$ yüzden ölümün tanımlanması (ölüm anının belirlenmesi) gereği doğmaktadır.

Ruh ile bedenin birbirinden ayrılmasını ölüm olarak tanımlayan teoloji biliminin bu açıklaması dindar kişiler açısından doyurucu ve yeterli sayılabilecekse de, soyutluğu nedeniyle, böyle bir yaklaşımın hukukçu

\footnotetext{
27 Velidedeoğlu, 11; Egger, Art. 31, N. 6; Grossen, 299.

${ }^{25}$ Egger. Art. 31, N. 6; Zevkliler/Acabey/Gökyayla. 217. Oğuzman/Seliçi/Oktay,11. Buna karşılik yaşama yeteneğine sahip olma koşulu ya da insan biçiminde doğmuş olma koşutu arandığı gibi bunların her ikisinin de birlikte olması koşultarłn arayan hüküm ve gôrüşler vardır. Bu konuda bak. Merz, 331 vd. ; Ataay, 39; Egger, Art. 31, N. 6; Wolf/Naujoks, 85 vd.; Zevkliler/Acabey/Gökyayla,218 vd.; Dural/Ögüz(Dural), 15 vd.; Oğuzman/Seliçi/Oktay,10.

ith Özunay (Hayat), s. 35

${ }^{27}$ Hinderling, 423. Fiziksel olümün bejirlenmesi anlık bir maddi olguya dayanan sorunu oluşturưr. Buna karşılık kişiye bağlı hakların kalkması hukuksal bir sorundur (BGE 118 IV 319).

I" Ölü hakkında dava açıłmasına ve hüküm kurulmasına yasal olanak bulunmadığı hk. bak. YIBBK T. 4.5.1978 S. 4/5 (YKD 1978, C. JV.865); Y. 18. HD E. 1996/4439, K.1996/4796, K 14.05.1996 (Yasa Hukuk Dergisi Y.19, C.15, 181, 2013,1014); Y. 10. HD E. 1990/10316, K 1990/10979, T. 20.12.1990 (YKD C. 17, Y. 1991, 4, 570 -572). Ölü kişiye kayyım tayin edilemeyeceği hak. bak. Y. 12. HD E. 1996/3896, K. 1996/5289, T. 16.4.1996 (YKD C. 22 Y. 1996, 7. 1082 . 1083,; Ölüınden sonra davanın tarafının mirasçıst olacağı hakkında: Y. 17. HD E. 2000/5401. K. 2000/5359, T. 23.11,2000 (YKD , C. 27, S. 1. s. 72)

${ }^{*}$ Zevkliler/Acabey/Gökyayla,494; Toroslu .105. Karş.2238 Sayılı Kanun md. 8.
} 
açısından son derece yetersiz kalacağı açıktır."3! Ancak hukukçunun da ölüm anının belirlenmesi konusunda fikir yürütmesi hem olası değil hem dc gerekli değildir..$^{31}$ Sonuç olarak duraksamaya yer verilmeksizin kabul edildiği gibi, bu konudaki yetkili bilim dalı olan tıp bilimine ve hekimlere başvurulmalıdır. Hukukçunun uğraş alanına giren ise tıp bilimi tarafından yapılan belirlemeler olacaktır. ${ }^{32}$ Olüm olayı da doğum olayı gibi kişisel duruma ilişkin kütüklerdeki kayıtlarla kanıtlanır (MK md.30, Nüfus K. md. 42). Kütükte kaydın bulunmaması ya da doğru olmaması durumunda ölüm olayı ya da kayıtların düzeltilmesi her türlü delille kanıtlanarak belirlenir (MK md. 7, 30, 38; Nüfus K. md. 33-40, 46) ${ }^{33}$.

Ölümün tanımlanması hususunda yüzyılı aşkın süredir titiz ve yoğun çalışmalar yapılmakta, bu konuda çeşitli yöntemler önerilnıektedir. Buna karşılık bilim alanındaki her gelişme, soruna ilişkin verileri değiştirmekte ve sorunun çözïmü gerçekleşmiş göriunmemektedir. ${ }^{34}$ Hukukumuzda ölüm anını tam olarak belirlemeye yönelik yasal bir düzenleme yoktur. Bununla birlikte 2238 Sayılı Organ ve Doku Alınması, Saklanması ve Nakli Hakkında Kanun'la ve yalnızca bu yasanın uygulanması yönünden ölülerden organ ve doku alımmasında ölüm halinin saptanması düzenlenmiştir. Anılan Yasanın 11. Maddesine göre "Bu Kanunun uygulanması ile ilgili olarak ubbi ölüm hali, bilinnin ülkede ulaştı̆̆1 düzeydeki kuralları ve yöntemleri uygulanmak suretiyle, biri kardiolog, bir nörolog, biri nöroşirürjiyen ve biri de anestezi ve reanimasyon uzmanından oluşan 4 kişilik hekimler kurulunca oy birliği ile saptanır." denilmektedir. Ayrıca bu konuda bir de yönetmelik hükmü vardır ${ }^{35}$. Aşağıda öncelikle bu konudaki belli başlı anlayışlara ve anılan hüküimlere değinilecektir ${ }^{36}$.

\section{1- Bjyolojik Ölüm Anlayışı}

Klasik ölüm anlayışı da denilen bu görüş gereğince ölüm, kişinin canlılığını sağlayan ve dolaşım, solunum ve sinir sistemlerinden oluşan (=büyük yaşam fonksiyonu) bölümlerinin işlevini yerine getirmemesi halidir ${ }^{37}$. Fizyolojik ölüm olarak da adlandırılan temel yaşam işlevlerinin

\footnotetext{
${ }^{30}$ Toroslu, 105

${ }^{31}$ Ayiter (Organ). 183-184

${ }^{32}$ Karş. Köprülü. s. 240.

${ }^{33}$ Köprülü. s. 243.

${ }^{34}$ Toroslu, 105.

${ }^{35}$ Organ ve Doku Nakli Hizmetleri Yönetmeliği ( RG 1,6.2000 S. 24066).

${ }^{36}$ Bu konuda geniş açıklamalar için bkz. Akıncı, 100 vơ.

${ }^{37}$ Bayraktar . 183; Zevkliler/Acabey/Gökyayla, 556; Özsunay, 213; Özsunay (Hayat), 37" "Tres sunt atria mortis, celebrum. pulmo, cor" (Ölüm üç yerden gelir: Beyin, akciğcr ve kalp)der eski hekimler. Buna bağlı olarak üç tür ölüm belirlenebilir: Beynin, neles almamin ya
} 
tümünün sona erdiği bu durumda son nefes ve son kalp atışı ile ölüm gerçekleşmektedir $^{38}$.

Tıp alanında ortaya çıkan yenilikler, klasik ölüm anlayışının, ölümü tanımlamada yeterli kıstas oluşturmadı̆̆ sonucuna varılmasına neden olmaktadır. ${ }^{39}$ Gerçekten bir kişinin solunumu ve kalbi tamamen dursa da, beynin canlılığı daha bir süre devam ettiği için, kalp masajı ya da yapay solunum gibi mïdahalelerle bu sistemlerin yeniden çalıştırılması mümkün olabilmektedir. ${ }^{40}$ Bunun gibi beden isısının düşürülmesi ya da bazı ilaçların enjekte edilmesi ile beynin canlılığının 30-90 dakika uzatılması mümkün olmaktadır. Ayrıca hastanın ameliyat sırasında dolaşım ve solunum sistemlerinin devreden çıkarılarak, bunların işlevini yerine getiren aygıtların kullanılmaları durumunda da bu sistemler görevlerini yerine getirmemektedirler. Böyle bir olastlıkta ise kişiyi ölmüş sayma yanılgılı sonuçlar doğuracaktır ${ }^{41}$. Bunun gibi sinir sisteminin tamamen durduğu, ancak kişinin kalbinin atmayı ve soluk almayı sürdürdüğ̈ü ayrık durumlar da söz konusu olmaktadır. Görünüşte ölüm (Scheintod) ya da yapay kış uykusu (künstlicher Winterschlaf) denilen bu gibi durumlarda kişinin yaşadığı duraksamasız kabul edilemeyecektir. ${ }^{42}$ Aynı şekilde, bedenden ayrılan kalbin bir süre daha çalışırılmasının mümkün olduğg durumlarda da, kişiyi canlı saymak olası değildir. ${ }^{43}$

\section{2- Beyinsel Ölüm Anlayışı}

Yaşama hakkı, insanı bütün kişilik görünümüyle korur; nasıl ortaya çıktığı, bir defalık ya da sürekli olup olmadığıyla ilgilenilmez. ${ }^{44}$ Başka bir deyişle, yaşamaya değer olmayan insan hayatı yoktur. Diğer yandan önemli bir husus da, insanın anayasa hukukunun bakış açısından ölü olarak kabul edilmesi, yaşamı sürdürmek için zorunlu koşul oluşturan bedensel işlevlerinin tamamen ve kesin olarak akamete uğramasıyla söz konusu olur. Böyle bir tanıya hangi kıstasların izin verdigine tıp bilimi karar verir. ${ }^{45}$ Özellikle son yıllarda reanimasyon (yeniden canlandırma) yöntemlerindeki

da kalbin durması yoluyla öłüm. Bunlardan biri diğerini de etkiler ve geri kalan organlar akamete uğrarlar" Wegelin. C. Altem und Tod, Bem 1951, 18 (Merz, 329, dn. 12'den naklen).

${ }^{38}$ Bayraktar. 183; Tekinay, 209. Ayrıca bak. Zevkliler/Acabey/Gökyayla, 556; Akıncı, 104.

${ }^{3 y}$ Güney Afrikalı Hekim Christiaan Barnard'ı 3.12.1967 tarihinde gerçekleştirdiği itk kalp nakti sonrasında, beyinsel ölüm anlayışı (brain death) geliştitilmiş ve ölün durumuyla ilgili Harvard Ölçütleri belirlenmiştir. Özsunay (Hayat), 37.

${ }^{40}$ Bayraktar, 183; Özsunay, 213.

${ }^{41}$ Merz, 331. Ayrıca bak. Zevkliler/Acabey/Gökyayla , 557

${ }^{42}$ Bilgin . 11 vd.; Wolf/Naujoks, 12: Bayraktar, 184; Aynca bak. Zevkliler/Acabey/Gökyayla, 557; Özsunay, 214; Öztan, 21.

${ }^{43}$ Bilgin, 11; ÖZtan, 22.

${ }^{11}$ Müller , 463; Schultz, 881. BGE 98 1a 108.

${ }^{45}$ Karş. Dural/Öğüz(Dural), 22; Bayraktar, 188/189; Arpacı, 184. 
gelişmeler gerçekleşmiş, bu gelişmeler ayn zamanda yoğun zorlukları da ortaya çıkarmışır. Yeni bilimsel gelişmeler , kalbin durması ve bunun gibi kan dolaşımının durması nedeniyle geleneksel ölüm tanısının geçerliliğ hususunda kuşkulara neden olmuștur. Tıp bilimi öğretisinde bugüin hemen hemen genel kabul gören düşünceye göre, kalbin durmast ya da kan dolaşımının durmasından çok kısa bir süre önce gerçekleşen beyin ölümü (yani beyin işlevlerinin tamamlanmış ve geri dönülmez [irreversible] biçimde sona ermesi) geleneksel ölüm anlayışıyla özdeş sayılmaktadır." Çünkü beyin bütün olarak sadece duyuların merkezi, bilincin ve bclleğin yönetim yeri değildir; aksine, aynı zamanda, kalp ve nefes alma işlemi, vüicut ısısının düzenlenmesi işlemi gibi çok çeşitli işlemlerin yönetildiği otonom vegatatif sinir sisteminin merkezini oluşturur. ${ }^{47}$ Nefes alma ve kalbin çalışmast işlevleri bugiin için ikame edilebilirken, beynin her hangi bir yolla tamamlanmış ve dönülemez hale gelmesinin etkisi ortadan kaldırılamaz." Beyin ölümú tanısı da geniş bir bilimsel tartışma açan zorluklar ortaya çıkarır. ${ }^{49}$

Yeni ölüm tanımı da denebilecek beyinsel ölüm anlayışına göre ölüm, bir kısım beyin hücresinin ölmesiyle başlayıp bütün beyin hïcrelerinin ölümü ile sonuçlanan bir süreçtir. ${ }^{\circ}$ Beyin hücrelerinin ölümüyle birlikte bedensel işlevleri, sistemleri kontrol eden ve düzenleyen beyindeki merkezler, görevlerini yapamayacak hale gelmektedirler. İşte böyle bir durumda,çeşitli fonksiyonlar arasındaki eşgüdümün bütünüyle durmassı ve birbirini tamamlamaktan yoksun hale gelmesiyle ölümün ortaya çlktı̆̆ kabul edilir :

1981 tarihinde Amerika Birleşik Devletlerinde Başkandık Komisyonu'nca geliştirilen ve Amerikan Tıp Derneği ile Amerikan Barolar Birliği tarafından benimsenen bir kanun tasarısıyla da beyinsel ölüme ilişkin olarak bazı ölçütler açıklanmıştır. Buna göre a) Dolaşım ve solunum

\footnotetext{
*. Özsunay(Hayat). 38

${ }^{47}$ Müller, 465 ; Luternauer, 77 ; Zevkliler/Acabey/Gökyayla, 557

14 Müller, 466; Zevkliler/Acabey/Gökyayla, 557

19) Karş.Geilen, 37.3 vd. 383 vd. Beyin ölümü sonrast, bir otyan ya da hücrelerin. yapay olarak sınırlı bir dolał̧ın sağlanması yoluyla yaşayacağı reddedilirse. bunun sonucunda yaş̧ama hakkı ihlal edilmiş olma7. (Müller, 466).

sal Beyinsel ölüm halinde bulunan hastalar gerçekte ölmemişlerdir. Ançak hunlă mutlisk biçimde ölüme gitmektedirler. Bunlar üzerinde uygulanacak her hangi bir tedisinin en ulak bir etki gösteremeyeceği durumlarda dahi hukuk. ölümün mutlak anlamda kesinli⿳̌冖̆ de değil. daha çok mutlaka gerçekleşeceğini ortaya koyan ve ölümïn gerçekte vuku bulmamış olabileceği en küçük kuşkuyu dahi bütünủyle ortadan kaldırmayan yöntemleri meşru sayamaz. Bu nedenle beyinsel ölümü doğrudan tespit yöntemleri ölüm anım tcspit yerise ölüm anını öne almaya hizmet etmemelidir. (Toroslu, 106 ve dn. 46). Karş̧. Bilgin. 15 val.

5 Bayraktar. [84, Zovkliter/Acabcy/Gökyayla, 557; Özsunay, :214: Bilg̣in, 17. Ayrtca balk. Akinci. 106
} 
fonksiyonlarının geri dönülemez bir biçimde sona ermesi; b) Beyin sapı dahil, beynin tümünün bütün fonksiyonlarının geri dönülemez bir biçimde durmast.

Bayraktar, beyinsel ölüm anlayışının hukukça da desteklenmesi gerektiğ̣ini ileri sürmektedir: "Buna göre insanın kişilił̧ini săglayan esas organ beyin ve bunun faaliyetleridir. Insanın çevresine uyması, hareketlerinin düzenlemesi beyne bağlıdır. Beynin fonksiyonlarını kaybetmesi ve bilincin ortadan kalkması halinde vücuttaki dolaşım ve solunum sun" $i$ olarak devam ettirmesi sadece 'görïnüşte bir hayat' sağlayacaktır" ". Buna karşılık beyinsel ölüm anlayışına eleştirel bir gözlükle yaklaşan bazı yazarlar, beyin kabuğunun bütünüyle tahrip olması neticesinde bitkisel hayata ${ }^{54}$ giren kişilerin ölmüş sayılamayacağına, ölümün saptanmasının bazan rastlantısal yöntemlerle gerçekleştiğine ilişkin çekinceler ileri sürmektedirler. ${ }^{55}$

Günümüzde beyinsel ölüm anlayışı duraksamasız kabul edilmiş olmamakla birlikte ${ }^{96}$. çeşitli ülkelerde bu yönde bir eğilimin olduğu söylenebilir. ${ }^{57}$ Ancak Dünya Tabipler Birliğg'nin 1968 yılında Sydney'de yaptığı toplantıda vurgulanan ve tıp biliminin sürekli gelişimi karşısında sıkı biçimde beyinsel ölüm kıstasına bağlı kalınarak bunun yasalaşmasına duyulan kuşku dikkate değer. ${ }^{5 k}$ Her halde çözüm, bugün için beyinsel ölüm kıstasını kabul edip, tıptaki ilerlemeleri takip ederek bu işi hekimlere

\footnotetext{
"s Ózsunay (Hayat) 38 'den naklen.

${ }^{53}$ Bayraktatr,185.

s Beyin ölümùne yönelik itirazların genellikle odağını oluşturan beyinsel ölüm ile bitkisel hayata girme olguları birbiriyle karıştırılmamalıdır. Bitkisel hayata giren kişide beyin ölümü belirtileri bulunmaž ve hastanın gözleri kendiliğinden ya da sesli bir uyar sonucunda açılabilir ancak hastanın izleme hareketleri yoktur. Hastada var olan uyku- uyanıklik döngüsü ile kan basıncı ve solunum kendiliğinden sürmektedir. Bu kişiler uzun yıllar yaşayabilirler. Buna karşılik beyinsel ölümde bu belirtiler bulunmaz. Bu yüzden de bitkisel hayata girmiş kişiler ölü kabul edilcmez, Bkz. Bilgin. 28, 29; Akıncı, 115; Özsunay, 215.

${ }^{55}$ Çeşitli eleştiriler ve bunlara kâşı jteri süirülen fikirler hk. bkz. Akınos, 106 vd. Tekinay'a göre beyinsel ölüm đüşüncesi, ozellikle organ nakli ameliyatlarının dikkate değer başarılar kaydetmeye başlamasindan beri hızle gelişmektedir. Bunun başlıca nedeni olarak, kalp nakilierinde . kälbi alınaçak kişinin ölmüş sayılmass için onun kalp atışlarının tamamen durmasına kadar beklenirse bu ameliyatları başarnyla yapılamaması görülmektedir. (Tekinay, 209).

\$i Kars. Özsunay, 214 ; Bayraktar.185; Zevklilet/Acabey/Gökyayla, 557; Dural/Öğüz (Dural), 21.

${ }^{57}$ Karşılaş̧ırmalı hukuk, özellikle Avrupa talkeleri ile ABD ve Kanada ' daki buna ilişkin gelişmeler hk. bk\%. Akıncı, $107 \mathrm{vd.}$

${ }_{5 \pi}$ Bununla birlikte Fiulandiya ve İspanya'da ölüm anı resmen bu açıdan belirlenmiştir. Ayrıca diğer bazı ülkejerde de ölüın anının resnen belirlenmemesine karşılık çeşitli sağlık kuruluşarının beyinsel öümü benimseyen bildiri ve kararlarına rastlanmaktadır. (Zevkliler/Acabey/Gökyayla, 482: Özsınay, 2l4-215\%.
} 
bırakmaktan geçecektir ${ }^{59}$. Bu anlamda 2238 sayılı yasada belirtilen, organ ve doku alınması ile ilgili olarak ölümün gerçekleştiğine dair verilecek kurul kararının, hukukçular açısında "bilimin eriştiği" noktaya uygun olup olmadığının belirlenmesi önemli olmalıdır ${ }^{60}$.

\section{B- Ülkemizde Durum}

\section{1- Genel Olarak}

Ölüm anının belirlenmesi açısından belirli bir sisteme bağlt kalındığında, tıptaki hızlı değişimlerin göz ardı edjlebileceği yolundaki Dünya Sağlık Teşkilatı'nın kuşkusı, Türk öğretisi tarafından da göz önünde tutulmaktadır. ${ }^{\text {to }}$ MK md. 28/1( Art. 31 Abs. 1 ZGB) kişiliğin ölümle soná erdiğini belirtir. Bunun dışında MK md, 31 (Art 34 ZGB) dışında Medeni Kanunda somut durumda ölümün tespitine yönelik yasal her hangi bir düzenleme getirmiş değildir. Yasa koyucu maddi olarak ölüm anını tanımlamaktan kaçınmıştır. Bunun nedeni ise yapılan tanımlamanın çok kısa bir süre içinde , bilimsel olarak anlamsızlaşacağına yönelik yasa koyucunun öngörüsüduir. ${ }^{62}$ Yasa koyucu çok kısa bir süre içinde bu tanımlamanın bilimsel olarak aşılacağını bilmekteydi. ZGB'nin yürürlüğe girmesinden itibaren gerçekleşen bilimsel gelişmeler yasa koyucunun bu çekingenliğinin dayanağını oluşturmaktadır. Gerçekten de on yıllar boyunca, kalbin geri dönülmez bir biçimde durması, kan dolaşımının, nefes almanın, yani asli yaşam fonksiyonlarını kaybı, ölümün tespiti açısından belirleyici kıstastar olarak görüilmüştür..$^{63}$ Buna karşılık yeniden canlandırma yöntemlerinin (reanimasyon) keşfi, geleneksel ölüm tanısı kavramının yeniden tanımlanmasını gerekli kılmıştır. ${ }^{64}$ Bu sonuçlar Objektif zamana uyğun tarihsel yorum açısından Art 31 Abs. 1 ZGB ye uygun olarak, bu hüküm tıp biliminin geliştiği aşama dikkate alınarak, bunun tarafından getirilen anlamda ele alınabilir. ${ }^{65}$ Ancak, ölüm anının kesin ve sağlıklı biçimde belirlenebilmesi için, hastanın yaşatılması yolundaki tıp aláını da varılan tüm yö̈temlerin denenmesi ve harcanan tüm çabalara karşın kişinin yaşamayacağı kesinlikle belli olması gerektiği gözden ırak tuculmamalıdır."."

\footnotetext{
${ }^{59} \mathrm{Karş.} \mathrm{Dural/Öğ(iz(Dutal),} \mathrm{22:} \mathrm{Bayraktar,} \mathrm{J88/189;} \mathrm{Arpacı,} 184$

"d) Karş. BGE 98 la $508,515$.

"1 Dural/Öğüzt(Dural), 22; Bayraktar. 188: Zevkliler/Acabey/Gökyayla, $557:$ Özsumą, 2I4-

215; Toroslu. 106 .

6. Huber, 73.

${ }^{63}$ Strártenwerth. 528 vd.

${ }^{64}$ Grossen. 303; Lutemauer, 77 vo.

${ }^{*}$ BGE 98 [a 508 vd.

'm Bayrak1ar . 188-189; Öz.sunay, 215; Dural/Öğüz(Dural). 20-21.
} 
Türk Tabipler Birliği'nin 18.4.1968 tarihli kararında ise beynin işlevini tümüyle yitirmesinin yanısıra tüm reflekslerin sona ermesinin birlikte oluşması halinde ölümün gerçekleşeceği belirtilmektedir. ${ }^{67}$ Aynı sonuç Ísviçre Tıp Bilimi Akademisi ve Federal Mahkeme tarafından da benimsenmiştir. ${ }^{68}$ Yükssek Sağlık Şurası'nın 24.11.1969 tarihli kararnda ise "bugünkii düşüncelerin en kuvvetlisi ve hakim durumda olan beyin fonksiyonunun tamamiyle durması halinin tesbiti seklinde kabul olunmuştur" denilerek ölümün belirlenmesi konusunda "beyinsel ölüm" anlayışı kabul edilmiştir ${ }^{(6)}$.

Yargıtay'a göre ise ölümün gerçekleşmesi için bütün organların işlevlerini yitirmiş olması getekir. Yargıtay I. Ceza Dairesinin 11.8.1972 tarihli kararına göre "ölüm anı bütün organlarının durduğu andır. ${ }^{\text {"70 }}$ Ayrıca ölüme kimin karar vereceği hususunda Umumi Hıfzısıhha Kanunu'nun 216 219. maddelerinde hükümler yer almaktadır.

\section{2- Organ ve Doku Aktarmaları Açısından}

2238 Sayılı Organ ve Doku Alınması, Saklanması ve Nakli Hakkında Kanun'la ve yalnızea bu yasanın uygulanması yönünden ölülerden organ ve doku alınmasında ölüm halinin saptanması düzenlenmiştir. Anılan Yasanın 11. Maddesine göre "Bu Kanunun uygulanması ile ilgili olarak tıbbi ölìm hali, bilimin iilkede ulaştığı dïzeydeki kuralları ve yöntemleri uygulanmak suretiyle, biri kardiolog, bir nörolog, biri nöroşirürjiyen ve biri de anestezi ve reanimasyon uzmanından oluşan 4 kişilik hekimler kurulunca oy birliği ile saptanır." Organ Nakli Merkezi Yönetmeliğgi ${ }^{71}$ ve daha sonra çıkarılan

\footnotetext{
${ }^{67}$ Buna göre ölüm anının belirlenmesi için şu koşullar aranmaktadır: 1-Jiki taraflı ve devam eden midriasis ;2-Bütün reflekslerin tam kaybı (derin hissiyatın kaybolması); 3- Solunum ve dolaşım spontan öalışmasının durması ve ancak reanimasyon tedbírleri jle sağlanması: reanimasyon tedbirleri yeterli sürece uygulandığ halde, normal solunum ve dolaşımı sağlanamayacağına dair karar verilmesi ; 4- Beynin fonksiyon yapmadığının EEG metoduyla tespit edilmesi, EEG'nin aktif bir belirti göstermemesi ve yeniden canlandırma metotlarıyla da aktif hiç bir belirti göstermemekte devam etmesi; 5- Ölümün tespiti için bu kriterlerin tek tek değil bünününün göz önüne alınması (Özsunay, 216'dan). Bu durumu Öztan, biyolojik ölüm olarak niteler. Bak. Öztan. 22.

* 25 Ocak 1969 tarihii "Richtlinien für die Definition und die Diagnose des Todes" (SJZ 65/1969.248; ZStR 1969.334; ZbJV 105/1969, 334); BGE 98 Ia 508.

${ }^{(H)}$ Bayraktar, 186. Ayrica bak. Toroslu, 108, dn.56.

${ }^{*}$ IBD 1972, S. 9-10,978,979.

${ }^{7}$ RG. 20.8.1993 21674. Bu Yönetmeliğin amacı. tedavisi doku veya organ nakli ile mümkün olan hastaların hayatiyetinj sürdürmek için nakilieri gerçekleştirecek organ ve doku nakli merkezlerinin, organ ve doku kaynağı merkezlerinin ve doku tipleme ünitelerinin açılması. çalışması ve denetimi ile bunların bağlı olduğu kannu kurum ve kuruluşları ile özel kuruluşların uymak zorunda oldukları usul ve esasları düzentemek, organ ve doku nakli hizmetlerinin yürütülmesinde uyulması gereken esaslan belirlemektir. (mo.1) Bu
} 
Organ ve Dok'u Nakłi Hizmetleri Yönetmeliğinin ${ }^{72}$ ekinde beyin ölümü kıstaslan sàyımıştır. Buna göre:

\title{
Beyin ölüm kiterleri:
}

Tanım: Beyin ölümü klinik bir tanıdır ve beyin fonksiyonlarmın tam ve irreversibl kaybidır.

\author{
İreversibj komanın temel bulguları
}

yönetmelikte getirilen kıstaslar daha sonra çkarılan Organ ve Doku Näkli Hizmetleri Yönctmeljŭ (RG । 6.2000 24066) ile daha farklı düzenlenmiştir (Bak. an.72'yc atit metin) Tanım: Beyın olümü klinik bir tanıdır ve beyin fonksiyonlarının tatn ve itreversibl kaybıdır. İreversibl komanın temel bulguları;

I) Komanın ał̧ağı

A-Primet hipotermi

B-Hipovolemik ya da hipotansif şok

C-Geriye dönüşïm sag̣|ayabilecek intoksikásyonlar(barbitürat ve diğer sedaliller. depresitn ve natkotik ilaçlar) ile metabolik ve endokrin bozukluklar

Ii) Bibincin tam kaybs

III) Spontan hareketin bulunmamast ve ağrolı uyaranlara yanıt altmmaması

IV) Spontan solunumun bulunmamas!

V)Beyin sapt retlekslerinin tatmamen kaybolması

A-Pupiller dilate ve/veya fiks, ışik reakisiyonu alınmaması

B-Kornca refleksi yokluğu

C-Vestibülo-okitiler refleks yok'luğu

D-Okilosefalik tetleks yokluğu

E-Pallatal ve trakeal reflekslerin yokiluğu

Vl) Apne testi(Pusil oksijen verilerek tespiratörün birkaç dakika çckilmesi ve spontan

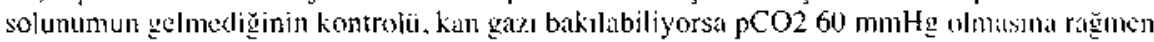
spontan solunumun bulunmamasi)

*Daha once tanısı konmuş bir nedenle hasta imeversibl koma tablosuna girmişse en a7 12

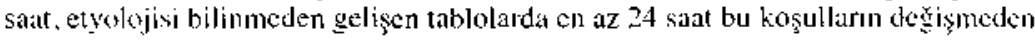

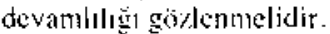

*Etyolojisi belirtenmemiş irreversibl komada. hekimler kurulunun uygun göreceği bir yöntemle klimk bulgular teyid edilebilir.

"Donör, beyin ötümü nedeniyle yaşamın yitirdikten ve bu durum kanumun öngördüçi biçimde lejid edildikten sonra donörün yókımına beyin ölümü deklare celilir

"RG I 6.2000 S. 24066. Bu Yonetmeli în amacı, tedavisi doku veya orọin nakli ile mümkün

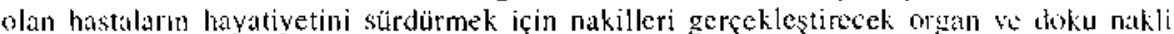

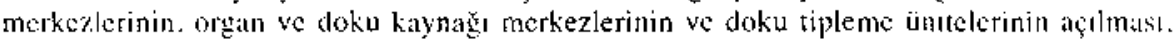

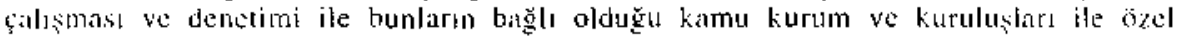
kuruluslaren uymak zorunda oldukları usul ve esaslar düzenlemek, organ ve deku nakli hizmetlerinin yürütülmesinde uyulmas gereken esasları belirlemektir (md. 2). Yömstmeliè in 32. madestes gereğinec. 20/8/1993 tarihli ve 21674 sayıl Resmi Gazeted vilymlanan ve $22 / 9 / 1994$ tarihli ve 22059 sayll Restini Gazetede yaymlanan Yonetmelikd de gistirilen Organ Nakli Merkezleti Yönctmeliği ve 20/8/1993 taribli ve 21074 snyll Resmi Gazatcde yalymbanan Kornea Náklinde Kornea Siğlanması ve Paylaşım Yömelmeliğ yürürlükren hirldirilmosill: 
I) Beyin ölümüne karar vermek için komanın aşağıdaki nedenlere bağlı olmaması,

a) Primer hipoterni.

b) Hipovolemik ya da hipotansif şok,

c) Geriye dönüşüm sağlayabilecek intoksikasyonlar (barbitürat ve diğer sedatifler, depresan ve narkotik ilaçlar) ile metabolik ve endokrin bozuklukları,

II) Bilincin tam kaybı,

III) Spontan hareketin bulunmaması.

Aşağıda bulunan durumlar beyin ölümü tanısını ekarte ettirmez.

a) Derin tendon reflekslerinin alınması,

b) Yüzeysel reflekslerin almması,

c) Babinski refleksi alınması,

d) Solunum benzeri hareketler alınmast, (omuz elevasyon ve adduksiyonu önemli tidal volum deģ̧şikliği olmaksızın interkostal genişleme),

e) Patolojik fleksiyon ve ekstensiyon cevabı dişındaki spontan ekstremite hareketleri.

IV) Ağrılı uyaranlara serebral-motor cevap alınamaması,

V) Spontan solunum bulunmaması,

VI) Beyin sap1 reflekslerinin tamamen kaybolması,

a) Beyin ölümünde pupiller parlak ışığa yanıtsız ve dilatedir (4-9 mm),

b) Kornea refleksi yokluğu, 
c) Vestibulo-oküler refleks yokluğu,

d) Okülosefalik refleks yokluğı,

e) Feringeal ve trakeal reflekslerin yokluğu,

VII) Apne testi:

Apne testi uygulanabilmesi için, Arterial $\mathrm{pO} 2$ ve $\mathrm{pCO} 2$ değerleri normal olmalıdır (pCO2 $40 \mathrm{mmHg}$ ve üzerinde). Bu koşullarda hasta $10-30$ dakika süre ile \%100 oksijen ile ventile edilerek arteriyel oksijen basmcmm $200 \mathrm{mmHg}$ üzerinde olması sağlanmalıdır. Bu koşullar sağlandıktan sonta hasta mekanik solunum desteğinclen ayrılarak trakea içerisine en az 8-10 dakika suire ile $6 \mathrm{lt}$. dakikada oksijen uygulanmalıdır. Bu uygulamalara rağmen spontan soluma yoksa apne veya kan gazlarmda pCO2 basıncı 60 $\mathrm{mmHg}$ veya üzerinde ise spontan soluma hareketi yoksa apne testi pozitiftir."

Yönetmelikte bu kıstasiar sayıldıktan sonra "hasta yakınına beyin ölümü deklare edildikten sonra organ bağış izni alınamadığında , hastaya uygulanan tıbbi destek kesilir" denilmiştir.

Gerçekleştirilen bu dỉzenlemelerle, öğretide en azından biyolojik öliume yeğ tutulan 'beyinsel ölüm' anlayışı benimsenip ${ }^{73}$ ölülerden organ ve doku alınması yönünden bu kıstúsa dayanılarak ölümün belirlenmesi işi esas olarak hekimlere bırakılmıştır. ${ }^{74}$

\section{III- Ceset Üzerindeki Hak ve Korunması}

\section{A- Genel Olarak}

Ölümle birlikte malvarlığı hakları mirasçıya geçer: kişiye bağlı olanları ise (örneğgn intifa, sükna gibi) sona erer ${ }^{75}$. Buna karşıllk ölüm sonralsı özellikle ölenin şeref ve itibarına ya da cesete karşı yapılan ihllalere karşı korumanın $\mathrm{kim}$ tarafından ve hangi yollarla yapılacağs sorunlarıyla karşılaşılmaktadır. Bu çerçevede ölümle ilişkili haklarmın ortadan kalktığı. nispi olarak devam ettiği yada ölenden başka kişilerin (özellikle yákılarm)

\footnotetext{
${ }^{73}$ Bilgin. 11 vd; Zevkliler/Acabey/Gökyayla, 557; Müller. 465.

${ }^{74}$ Bayraktar, 188, 189; Dural/Öğüz(Dural), 22; Toroslu. 108.109. Ayrıca bak. Akıncı. 111. Olüm anımon bulirlenmesine yönelik olarak Isviçre Tıp Bilimleri Akudemisi taratindan çkarılan yönergenin anayasaya aykırılık oluşturmaklığ hakkinda bak. BGE 98 ia 508.

Velidedeorlutit24.125.
} 
kişilik hakları çerçevesinde korumanın sağlanabileceği düşủnceleri ortaya çıkmaktadır. Bununla birlikte ceset üzerinde tasarruf edilebilip edilemeyeceği ya da hangi oranda edilebileceği konuları da her kes için üzerinde anlaşlan konular olmaktan uzaktır. Bu bağlamda konunun ahlak boyutuna da değinmenin yararlı olacă̆ ${ }_{1}$ düşüncesindeyiz. Çünkü, hukuk ve ahlak tamamlayıcı bir biçimde insan davranışlarını duizenlerler. Bu bağlamda birbirleriyle kısmen etkileşim içinde, kısmen de her bir alan bireysel olarak kendi varlıklarını sürdürïirler. Aşă̆ıda, anılan çerçeve içinde, ölüm anının etkileri üzerinde durulacaktır.

\section{B- Kişilik, Hukuk ve Ahlak Arasmdaki İlişki Çerçevesinde Ölümün Etkisi}

Mahkeme kararlarında Anayasal bir düstur olarak nitelenen kişisel özgürlük ilkesi, insanın kişiliğini geliştirmeye yönelik asli görünümlerini içeren her türlü özgürlüğü sağlamayı amaçlar. ${ }^{76}$ Anayasanın koruması içine her şeyden önce bizatihi kişinin yaşamı girer (AY md.17). ${ }^{77}$ Anayasa Hukuku açısından yaşama hakkı kendisini diğerlerine karşı belirginleştirir, bireysel özgürlüğü sağlayan temel ilke olan kişiliğin korunması yoluyla, bilerek yapılan her saldırı mutlak olarak korunan varlığının ihlali doğurması nedeniyle anayasaya aykırılık oluş̧urur ${ }^{78} \mathrm{Bu}$ nedenle yaşama hakkı her hangi bir biçimde sınırlanamaz: yasal temele dayanan ve kamu yararımı ilgilendiren ihlaller, anayasa hukuku açısından düşünuilemez. ${ }^{79}$.

Genel bir kanaat olarak ahlak (etik) haklılıktan ve izin verilebilirlik anlaminda hukuksallıktan o kadar uzak değildir. Buna karşılık hukuk normları kural olarak ahlaksal kurallara göre daha dar bir standart ortaya koyar. Çok açık olarak bu bağlamda hukuktan kısaca " asgari ahlak" olarak söz edilir. "Buna karşılık hukuk, emirler koyması ve bunun uygulanmasını ortaya çıkardığı cebir aracılığıyla garanti etmesi ve buna bağlı olarak da saf anlamda ahlaksal kurallara göre eylemli olarak yüksek bir bağlayıcılık derecesi göstermesi neticesinde "azamî ahlak" biçiminde ortaya çıkar. Buna bağlı olarak Kant'ın meşruluk (Legalitaet) ve ahlak (Moral) ayrımı anlamındaki hukuk ve ahlaktan (Ethik), ahlak ayn zamanda "saik" yani ahlaken kabul edilebilir bir güdü olarak anlamlı olmasına karşılık, hukukun

\footnotetext{
${ }^{76}$ BGE 97 [ 49 Erw. 3.842 Erw. 3.

$\pi$ 3.10.2001 Tarihli ve 4709 sayılı Yasa ite Anayasaya "Savaş, çok yakın savaş tehdiḑi ve terör suçları halleri dışında ölüm cezası verilemez" hükmü eklenmiştir.

${ }^{78}$ BGE 97 I 50: Müllet, 46.

${ }^{79}$ Müller, 462; BGE 98 Ia 508 vd.

"Jellinek, 45; Taupitz, 4. Güriz'e göre hukuku asgari athlak olarak değerlendiren yaklaşımın doğru olmadığı söylenebilir. Bu bağlamda ömeğin şehirlerarası yollardan yüksek hız düzeyini belirleyen ve bunu $90 \mathrm{~km}$ olarak saptayan kuralın ahlak ile her hangi bir ilişkisi yoktur. (Bak. Güriz, 24)
} 
bireyin norma uygun dış davranışları olması açısından ayrılır. ${ }^{* 1} B$ anlamda Hukuk dışa yansımayan insan davranışlarıyla ilgilenmez. Ancak bir davranış dişa yansidıkıan sonra, kişinin hangi saikle o davranışta bulunduğgu önem kazanır. Bireyin kendi iç yaşamı ile ilgili olan ve dışa yăsımayan davıanışları ahlakın jlgi alanında değerlendirilir. ${ }^{k 2}$

Aynı zamanda hukuk çok yönlü olarak ahlakın hukuksal alanda doğrudan kapsanmasına çalıșı (ahlakın da tamamen hukuksal dưşünceden ayrı hareket edememesi gibi): "Dürüstlük (iyiniyet) kurállarma aykırı hukuksal işlemler hukukça korunmaz" (MK/ZGB md.2: BGB ş 138) biçimindeki bir kural, hukuk ve ahlakın birbiriyle bağlantısız biçimde yan yana durmasına değil, aksine hukukun çok taraflı olarak ahlakın değerlerini ïzerine almasına çabalar ve onu " hukuku takdis makamı" dedirtmemek için bir uygulama gücui verir. Buna karşılık hukukun bilinçli olarak temelsiz ahlak çkarmmlarmı gözü kapalı kabul edeceği anlamma da ulaşılamaz. Çünkü hemen her zaman olduğu gibi, uygun aktarma bağlantıları biçimlenerek yerleştirilmiştir: Ahlaksal değerlerin hukuka aktarıması, hukuk düzenindekj diğer isterlere ve özellikle anayasal gereklere olabildigince uygun olmalıdır. Öneğin ahlaksal bir yükümlülük olarak ortaya çıkan aile bireylerinden birine kan ya da böbrek bağgşı hukuksal bir yükümlülük olarak mevcut değildir ${ }^{k 3}$.

Sonuç olarak her toplum kendi hukuk düzeni ve toplumun diğer yönlendirici etmenleri arasında bir iş bölümünü işaret etmelidir. Bu her şeyden önce yaptırımla donatılmıs hukuk normlarının, temelde sadece son seçenek (ultima ratio) olarak ortaya konulması anlamında geçerlidir. Anciak bunun dışinda sosyal, ahlaksal, dinsel ya da bir meslek grubuna özgü ahlak temelli normlar, birlikte yaşamm işlerliğini - aynı zamanda bireyin ölümü hakkında da- güvence altma alır. ${ }^{8-1}$

\section{C- Cesedin Medeni Hukuk Açısından Niteliği}

\section{1- Genel Olarak}

Hukuk ve ahlakın karşıltklı olarak birbirine nüfuz etmesi ve ethileşimi açısından dikkate değer bir nokta "insan kime aittir-kendi bedeni üzerinde mülkiyet hakkı var mudı" sorusudur. Ortak hukuk öğretisinde (Gemeinrechtslehre) ceset, mülkiyete konu olabilecek bir şey kabul edilirdi.

\footnotetext{
"Taupitz. 4. 5

¿: Güriz, 23.

"Taupit..5.

it Taupity 4.

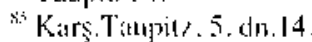


Bu dïşüncedekiler görüşlerini çeşitli hukuksal dayanaklarla kanıtlamaya çalışmışlardır. Bir đüşünceye göre ceset sahipsiz bir maldır:Bunun nedeni ise daha önceden var olmayan şeyin ölüm yoluyla ortaya çıkmasıdır; bu malın sahibinin ölümden önce yaşayan kişi olduğu dưşuinülse bile artık bu kişi de yoktur. Yasada da cesedin terekeye dahil olacağı konusunda bir açıklık bulunmamaktadır. Bu durumda ceset hakkında sahipsiz mallara ilişkin Medeni Kanunun 691. Maddesi uygulanmaltdır. Bunun gibi cesedin ticari alana dahil olmayan bir şey (res extra commercium) ya da mirasçıların mülkü olduğu görüşleri de ileri sürülmüşşür. ${ }^{86}$

Günümüzde ise ceset üzerinde bir mülkiyet hakkının olmayacağı kabul edilmektedir. ${ }^{87}$ Başka bir deyişle ceset - aynı yaşayan insan gibi - mülk olarak kabul edilmeye uygun bir şey değildir; en azından "kişilik hukuku" boyutu "eşya hukuku" boyutunun gölgesinde kalır. ${ }^{88}$ Cesedin daha önceki kişi ile olan bağlantısı tamamen kopmuşsa; bu durumda geriye kalan, örneğin anatomideki bir iskelet gibi, eşya olarak görülebilir ${ }^{89}$ Ancak cesedin eşya olma özelliğine ne zaman ulaşacağı ile ilgili sınır oldukça muğlaktır ve tek başına geçen zaman, bu sınırı tayin etmek için yeterli değildir ${ }^{90}$.

\section{2- Ceset Üzerindeki Hak ve Kişilik Hakkı}

Ceset üzerindeki hakkın kişilik haklarıyla olan bağlantısı açısından öğretide farklı düşünceler ileri sürülmektedir. Bunları aşağıdaki gibi gruplandırmak olasıdır.

\section{a) Ölenin Kişiliğinin Ölümle Sona Erdiğine İlişkin Düşüinceler}

Türk/İsviçre hukuku açısından Öğretideki baskın görüş gereğince kişiliğin ölümden sonra sürdüğü kabul edilemez." Kanunumuz kişiliğin ölümden sonra *kısa bir süre de olsa- sürmesini kabul etmemiştir ${ }^{92}$. Ölüm ile kişiye bağlı olmayan haklar mirasçılara geçer. Miras yoluyla geçmeyenler

\footnotetext{
Atabek, 192 vd.

${ }^{x 7}$ Ayiter (Organ), 181; Özsunay, 211: Egger. Art 31. N. 15; Dural/Öğüz(Dural). 26; Öztan, 23; Zevkliler/Acabey/Gökyayla, 452; Oહ̌uman/Seliçi/Oktay, 16. "Insan cesedi ile cesedin parçalan da ilke olarak hukuki işlemlere, mülkiyete konu olamaz. Ancak istisnai olarak, ölen şahsın veya yakınlarının kişilik haklarımı koruyan hüküınlerin sınırları içinde kalmak, bunlar ihlâl edilmemek şartıyla ceset. ayni haklara ve bu arada millkiyete konu olabilir" (Gürsoy/Eren/Cansel, 374'den naklen). Karş. Atabek, İBD, s. 629

ss Deutscly, 253: Taupitz. 8.

${ }^{8 y}$ Deutsch. 253; Taupitz. 8; Gürsoy/Eren/Cansel. 374.

*' Taupi\%. 7 .

${ }^{91}$ Egger:Art.31.N.15; Özsunay, 211: Özsunay (Hayat), 37; Ataay,: 248; Ataay, (MHAD), 28; Zevkliler/Acabey/Gökyayla. 452.

Ataay. 248: Egger. Art. 31 N. 15.
} 
ise ortadan kalkar (örneğin intifa, nafaka iradı gibi). Ancak kişiliğin bazı etkileri ölümden sonra da sürer. Kişinin bedensel varlığının yeryüzündeki kalıtı olarak cansız beden kalır. Bunun yanısıra, kişiliğin toplumsal görünguilerinden olan şeref, saygınlık, giz alanı gibi değerler hukuksal korunmadan yararlanarak etkilerini sürdürürler. Söz konusu hukuksal korumadan yararlanma, ölenin kişiliğinin sürmesinden ya da geriye bazı kalıntıların kalmasından kaynaklanmaz. Çünkü hukuk düzeni yaşayanlar için getirilmiştir. Ölü ise artık insan topluluğunun bir uyesi değildir. Bu yiizden de korumanın konusunu yaşayanların ölüye karşı besledikleri hürmet ve saygı duyguları oluşturur. . $^{93}$

Öğretide baskın olarak ceset üzerinde ölenin yakınlarının haklarının olduğu kabul edilmekte ancak bu hakkın niteliği konusunda değişik fikirler ileri sürüulmektedir. ${ }^{94}$

Öğretide savunulan ve baskın görünen görüş gereğince ise, ceset üzerinde yakınların kişilik hakk ${ }^{95}$ söz konusudur. Ceset üzerinde korumanın konusunu, hayatta kalanların ölene karşı besledikleri hürmet ve sayģı duyguları oluşturur. " Yakmların duygusal yaşamları ve kişiliklerinin ruhsal varlıkları söz konusudur. Ceset üzerindeki hak da bu şekilde açıklanabilir." Bir diğer düşünceye göre ise kişinin cesedi üzerinde bir kişilik hakkı olduğu söylenemez. Buna göre ölenin yakınlarının ceset üzerinde kendine özgü mutlak bir hakkı vardır. ${ }^{48}$ Ceset üzerinde yakm aile bireylerinin, ikinci derecede de mirasçıların mülkiyet benzeri mutlak hakları söz konusudur. Bu hakkın mutlaklığı mülkiyet hakkındakine benzer bir etki yaratır. Ancak bunun kendine özgü (sui generis) bir mutlak hak olarak kabul edilmesi gerekir. Ceset izerindeki bu hakkm içeriği gelenek hukukuna göre, gelenek hukuku olmadığı durumlarda da yargıcın hukuk yaratma yetkisiyle belirlenecektir. Ceset üzerinde öncelikle kimin söz sahibi olduğu ise (gömülme biçiminin. yerinin belirlenmesi ya da cesetten bir parça alınması gibi) yine gelenek hukukuna göre belirlenir ${ }^{\text {ty }}$.

${ }^{20}$ Egger. Art. 31, N.15.

${ }^{2}$ Bak. Dural/Öğüz (Dural), 26, 27; Öztan, 23 vd; Zevkliler/Acabey/Gökyayla . 451 vd.; Özsunay. 212 vd.: Egger, Art. 31. N. 16.

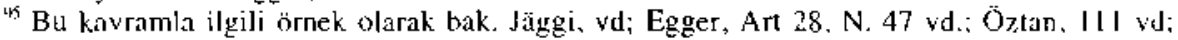
Dural/Öğĭz(Dural). 97 vd: Oğuzman/Seliçi/Oktáy, 115 vd; Velidedeoğlu. 81 vd.: Köprülü. 262 vd: Zevkliler/Acabey/Gökyayla, 441 vd.; Akipek/Akıntürk. 105 vd.

th Özunay. 211; Ataay. 129-130: Atabek. 194; Egger, Art 31. N.10; Dural/Öğüz (Dural). 26:Oğuzman/Seliçi/Oktay. 16: Arpacı. 129.

${ }^{177}$ Jiggí. 168: Egger. Art 31. N.17.

"Ayiter (Oran). 181. ayn fikirde Zevkliler/Acabey/Gökyayla, 452.

${ }^{*}$ Kass. Oztan. 25 


\section{b) Ölenin Kişiliğinin Ölümden Sonra Sürebileceğine İlişkin Düşïnceler}

Eğer hukuk düzeni öncelikle açık emir ve yasaklar yoluyla belirli davranış biçimleri göstermez ve buna bağlı olarak emir ve yasaklara aykırı davranılması halinde karşılaşılacak olan yeterli yaptırımları tam olarak tespit edemezse , tıp alanında ceset sorunsalı ile ilgili yaklaşımlar, hem tıp hem hukuk alanı için yetersiz tanıların dogmasına yol açacaktır: Yalnızca esasların açıkça belirtilip, geri kalan kısmın somut olayın koşullarına gönderme yapılması biçimindeki yaklaşım ise ancak (aslında yetersiz olan) yaptırım korkusu aracılığıyla sağlanacaktır. Diğer bir bakış açısından, "hukuksal güvenlik", "hukuksal açıklık" ve "öngörülebilirlik" amaçları, gerçi tutturulması gerekli bir düzey olarak ileri sürülebilir, ancak buna karşılık "yeni sorunla baş edilebilmesi için uyumluluk niteliğgi" ve "eşit olmayanlara eşitsiz davranmak için ayrım yapabilme gereği" eşitliği sağlayıcı götürü çözümler yerine, aynı derecede gereklidir. Buna ek olarak, hukuk diizeni aynı zamanda, özgür bir toplum için gerekli olan işlem serbestisini sağlamak için çabalamalı ve yaptırımla donatılmış emir ve yasakları toplumun tümünden çıkan (aynı zamanda ahlaki ve politik olarak) uyuşmayla olan bağını koparmamalıdır ${ }^{100}$.

Yaşama hakkı kişisel özgürlüklerin temelidir ve sınırsız olarak geçerlidir. ${ }^{101}$ Fakat burada tartışmalı olan kısım, "kişilik hakkının" ölen insanı etkileyip etkilemeyeceği veya nasıl etkileyeceğidir. Bu durumun tartışmalı olmasının nedeni ise, sadece yaşayan bir insanın bir hakka sahip olmasından ileri gelmektedir. Bu konuda sıkça kullanılan "postmortal (ölüm sonrası) kişilik hakkı" da yanılgıya düşürmemelidir. Yani, ölen kişiye, hak ve fuil (eylem) ehliyetinin yetersizliği yüzünden, böyle bir hakkın sahibi olarak bakılmaz ${ }^{102}$. Medeni Kanunun 27. maddesi metnine göre kişilik ölümle sona erer. ${ }^{103}$ Kişiliğin ölümden önce sona ermesi olası değildir. Çünkü kişinin sırf insan olmasından kaynaklanan ve irade ile ortadan kaldırılamayacak hakları söz konusudur. Ancak kişilik ölümden sonra sona erebilir mi ? Yani hukuksal kişiliğin, fiziksel kişilikten daha uzun sürmesi olası midır? ${ }^{104}$ Konuya değinen DEUTSCH, anayasada temelini bulan insan onuru $^{105}$ prensibinden hareketle, devletin, tek tek kişilere insan onuruna

\footnotetext{
inin Taupitz , 4 .

IUI BGE 98 Ia 508 .

102 Taupitz, 8 .

${ }^{303}$ Bu durum yeni ( 1998 tarihli)Medeni Kanun Tasanst'nda da ayn biçimde ancak 28. madde altında düzenlenmiştir.

${ }^{134}$ Egger, Art .31 N. 15.

"is "İrade özerkliğinin önemli bir görünümü, insan onıruna ilişkin haktır (right to human dignity) . Onurumuz üzerindeki hak, tıbbi müddahale ve tedavi bakımından insanın bir "araç" değil fakat "amaç" olarak gözönüne alınmasımı gerekli kılmaktadır" (Özsunay(Hayat), 35 'den
} 
yönelik olarak gelişen saldırılara karş1 ölümlerinden sonra da koruma sặ̆lamakla yükuimlü olduğu sonucuna varır. Bu bakış açısı ile bakıldığında, dogmatik baizı sorular göz ardı edilerek kişilik hakkınm insanın ölümünden sonrasını da etkilediği kabul edilmelidir" ${ }^{(1)}$, ve bunun en ikna edici yolu bu hakkın bir devamlılık yöntemi şeklinde (her ne kadar devredilemez ve miras olarak bırakılamaz gibi görülse (le) güvenilir kimseler olarak yakmiarma devredilmesidir ${ }^{117}$.

Buna karşıllık, iki yönlü bir bakış açısı ile bakıldığ̣nda . kişiliğ̣in ölümden sonra da korunması mümkündür: $\mathrm{Bu}$, bir yandan yaşayan kişinin kişilik hakkı veya bunun açık belirtilerinin ölümden sonra ortaya çıkan sonucun art etkileri ile (örneğin ölen kişinin yaşadığı dönemde kişiliğin özgür gelişimi çerçevesinde vermiş olduğu kararlar -nerede ve nasıl gömülece s̆i, otopsi ve gen analizi v.b.- ölümden sonra tartışmasız olarak geçerlidir) ilgilidir. ${ }^{10 \%}$ Öte yandan böyle bir talebe, bu tïr ihtilafłı durumlarda ödenen maddi tazminatın sonuç olarak bir ücret oddeme anlamına geldiği ve verilen veya reddedilen bir onamanın endişe verici bir ticurileşmeye yol açabileceği gerekçesi ile ilke olarak karşı çıkılmaktadır. ${ }^{110}$ Buna bağ ı olarak. kişiliğin ölümdel sonra da sürdügünün kabul edilmesi gerektjğini ilcri süren yazarlardan SEROZAN'a göre ölümle kişiliğin sona ermesi düşüncesi "ölüyle ticaret yapılmasına, ölü sayesinde yüksek tutarda tazminatlar clde edilmesine. Yarğtay an sözcüklerini kullanmak gerekirse, kişiferde 'yakınlarının ölmesi arzusunun kökleşmesine' yol açábilecek sakııncalı bir görüştür." ${ }^{100}$ Yazar, bu görüş yerine kişilik hakkının ölüm sonrasında belirli bir art-etki (post mortal etki) saçtı̆̆ının kabul edilmesi gerektiğini savunmaktidır. Yazara göre "böylece ölenin cesedine, mezurma, onuruna, saygınlığına, eseri üzerindeki manevi haklarma yönelik saldırılar karł̧sında. yerine göre, evvelce kendisi tarafından atanmıs olan vasiyetj tenfiz memuru ya da belirli yakmları, salt ölenin çıkarlarmı ve kişilik hakkın dikkate alarảk onun açık ya da varsaylı (farazî) dileklerine uygun bir hukuksal korumayı gerçekleştirebilir." "11 Yazar, bu fikirleri ileri sürdüğu makalesinde, ölenin yakınlarımın ölenin kişilik haklarma saldırıldı ğı getekçeșiyle manevi giderim (tazminaı) istemelerini de hukuk mantığma aykurı sayarak, bu kişilerin.

nakletı). Kars . AY mal. 12. "Avrupa Anayasalarının hemen hemen hepsinde insan hakkarının

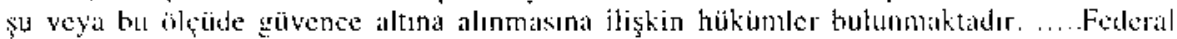

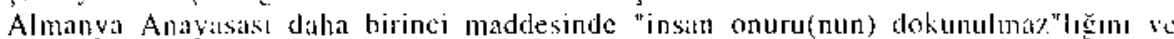
"dokunulmia. devredilmez insan haklatı"n devlet düzeninin temeli olarak belirtmiştir. ....Kezal lisvec Anatyasist da 2. maddesinde kamu yetkisinin herkesin eşit değerige ve "bireyin

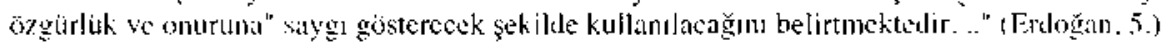
lis Deutsch, 2(x).

${ }^{k 17}$ Deutsch. 260) Titupt\%. 8

"1"Bs BHG. NJW-RR 1992.834 vd: Öztan. 121.

"1"s" Serozan, 109: Titupitz, 8; BGH, NJW-RR 1992.834 vd.

I1" Serozatt. I119. Kalrs. Arpaci, 129.

"II Seromall. 10 y. 
paranın mezardaki ölünün gönlünü almayacağı gerekçesiyle tazminat dışı koruma yollarını seçmeleri gerektiğini belirtmiştir. Yazar'a göre pozitif hukukumuzdaki çeşitli hükümler bu görüşü desteleyecek niteliktedir. ${ }^{122}$

Fakat burada asıl soru, bu şekli ile kendi parasal çıkarı için başkasına saldıran birisinden başkasını korumaktan başka bir işe yaramayan bu durumun, doğru olup olmadığıdır. Bu durumda kurbanın korunması ilerleme kaydedemezken, ticarileştirme argümanı ile faile düşündürǘcü bir ayrıcalık sağlayan bir sonuca ulaşılmaktadır..$^{113}$ Sadece çok nadir durumlarda akrabaların da failin elde ettiği kazançtan pay almaları mümkün olacaktır. Fail gerçekte ölen kişinin ölüm sessizliğinden yararlanıp kendi cebini doldurmaktadır. ${ }^{114}$

Kişiliğin ölümden sonra korunması sorununa değinen HATEMİ ise görüşlerini şöyle temellendirmektedir ${ }^{115}$ : Tıpkı cenine yaşam hakkı tanınmasının, kişiliğin doğumdan önce ve devlet makamlarınca korunarak pratik bir gereksinimin karşılanmasında olduğu gibi, ölümden sonra ortaya çıacak ihlallerin de yine bir devlet makamı tarafından ve pratik anlam taşıması itibariyle korunması gerekir.Ideal bir düzende yapılması gereken bu düzenlemeyle mirasçılar yararına değil, bir hayır kurumu yararına bir tür özel para cezası niteliğindeki "manevi tazminat" isteminde bulunabilecek devlet makamına bu konularda yasal temsil yetkisi verilmelidir.

Ancak genel kişilik hakkı ölen kişinin medeni hukuk açısından korunması için bir çıkış noktası olarak kullanılmaya hazırken, medeni hukuktaki yaptırım aracı yinede kör bir silah olarak kalmaktadır: akrabalar kural dışı bir otopsi, organ nakli yada izni alınmamış bir deney sonucunda kural olarak maddi veya parasal bir kayba uğramadıklarından, sadece ceza gerektiren eylemi kabuI etme anlamında manevi zarar vermiş olmaktan dolayı yakınlara manevi tazminat ödenmesi söz konusu olabilir (Kar. BK md. 47) ${ }^{116} \mathrm{Bu}$ düşünce gereģince de ölümden sonra kişiliğin belli bir süre daha devam ettirilmesi ve bu korumanın yakinları ya da daha önce belirlenecek kişiler yardımıyla sagłlanmasının de lege ferenda olumlu olacağı fikrini paylaştığımızı belirtmeliyim. ${ }^{117}$ Buna karşılık yeni bir yașal düzenleme yapılana dek sorunun ancak baskın düşüncenin kabul ettiği, yakınların kişilik haklarının korınması bağlamında çözümleneceği olgusunı tespit etmekte de yarar vardır

\footnotetext{
"1? Setozan, 110. Yazar BK md. 47 gereğince ölenin yakınlarına ödenecek manevi tazminatı bu kapsamın dışında tutmaktadır (Serozan, 110 ).

${ }^{113}$ Taupitz,9.

${ }^{11+}$ Taupitz, 9 .

115 Hatemi .105.

II" Taupitz. 9

${ }^{17}$ Bak. Öztan, 25
} 


\section{D- Ceset Üzerinde Yapılacak Tasarruflar}

Olăgan bir eşya niteliği taşımadığı için ceset üzerinde egemenlik kurulamaz. Bunun gibi kural olarak cesedin parasal bir değeri yoktur ve hukuksal işlemlerin konusunu oluşturmaz. ${ }^{118}$ Ancak ceset ìzerinde hukuksal bir koruma söz konusudur. Ayrica Ceza Kanununda da ceset "mezar"a ve ölüye karş1 yapılan tecavüzler" 119 cezalandırılarak korunmaktadır. ${ }^{120}$ Bunun yanısıra 17.6.1982 tarihli "Insan Cesedi Üzerinde Bilimsel Araştırma Yapılmasına İlişkin Yönetmelik"121 ile de ceset üzerinde bilimsel çalış̧ma yapmanın koşulları açıklanmıştır. Bu yönetmeliğin amacı 2238 Sayılı Kanunun 14. maddesinde sağlıkta bağışlanan cesetlerle, kimsenin sahip çıkmadığı ve adli kovuşturma ile ilgisi bulunmayan cesetlerin. Yükseköğretion Kurumlarına bilimsel araştırmalarda yararlanılmak üzere gönderilmesi, korunması, def'in ruhsatı dahil, tabi olacakJarı işlemleri belirlemek olarak açıklanmıştır (md. 1). Anılan yönetmelik anlamında "vasiyet edilen ceset" deyiminden, sağlığında, ölümünden sonra inceleme ve araştırma faaliyetlerinde faydalanılmak üzere vücudunu băğı̧layan kimseler ait cesedin anlaşılacağı $3 b$ hükmünde belirtilmiştir. CMUK'ta da ceset üzerinde yapılacak otopsiye ilişkin hükümler mevcuttur (md. 79-83).

\footnotetext{
${ }^{118}$ Ataay, 130; Zevkjiler/Acabey/Gökyayla, 453; Ayiter(Organ), 181: Dural/Öğìz(Dural), 26. 2238 Sayılı Kanun md. 3 ve Insan Cesedi Üzerinde Bilimsel Araştırma Yapılmasına Jilşskin Yönetmelik (RG. 17.6.1982. S. 17727) md. $7 / 1$ gereğince parasal çıkar karş1lığı ceset vasiyet edilemez ve ceset sağlanamaz; cesetlere, bir ölüye gösterilmesi gercken ałami saygı gösterilir Avrupa Konseyi Ínsan Hakları ve Biyotıp Sözleşmesi (Convention for the Protection of Human Rights and Dignity of the Human Being with Regard to the Aplication of Biology and Medicine: Convention on Human Rights and Biomedicine[4.4.1997 Oviedo/Ispanya'da imzaya açılmış ve Türkiye tarafından 7 Ağ ustos 1997 tarih ve $97 / 9767$ kararla anlaşma (birzı çekincelerle) kabul edilerek 18 Kasım 1997 tarihinde Genel Sekreterlikte tescil edilmişsir]) 6(4) maddesi gereğince, Insan vücudunurı hiçbir parçası ticari amaç için kullatılamaz.

119 TCK. Madde 178 - (Değişik: 9/1/1986 - 3255/4 md.) Bit kimse, bir olïtiün naaş ve kemikleri hakkında hakaret yapar veya tahkir maksadıyla veya meşru olmayan diğcr bit maksatla birinin naaşını yahut kemiklerini ahırsa, ü̧̧ aydan bir yıla kadar hapis ve beşbin liradan yirmibeşbin liraya kadar ağır para cezasıyla cezalandırılır. Bunların dışında, her kim bir ölünün naaşını tamamen veya kısmen alır veya ruhsat almaksızın bir nasşı mezardan çıkarır yahut kemiklerini alırsa, iki aydan altı aya kadar hapis ve beşbin liradian yirmiţeşbin liraya kadar ağır para cezası ile cezalandırılır. Eğer bu cürüm kabristanda veya ölü gömülmeye veya muhafazasına mahsus diğer yerlerde görevli olan yahut kendilerine naaş ve kemikler tevdi olunan kimseler tarafından işlenirse, yukanda yazılı cezalar bir misli artırıłarak hükmolunur.

${ }^{13)}$ Bu konudaki ilginç bir Yargıtay kararı için bkz. Y. 4. CD. 2.4.1975 tarih ve E. 1975/2433, K. 1975/3150 (Bu kararda yakınlarının iznini almadan cesetten başka hastaya góz nakleden hekimlerin TCK. 178/I'de düzenlenen "Mezara ve älùye yapılan tecavǚ "suçundan dolayı sorumlu tutulamayacakları belirtilmektedir. Güner , s. 587 vd.) Bununla birlikte cesctten bir parça (göz) alınmasının ölenin miraş̧ı ve yakınlarının kişilik haklarına aykırılık oluşturduğundatn dolayı, operasyonu yapanlar hakkında açılan manevi tazminlat davasında tazminata hükmedilmesi gerektiğini kabul eden başka bir Yargıtay kararı için bkiz. 4. HD. 10.3. 1977 tarih ve E. 3455, K.2751 Saylh Karan (Karahasan. s.1345-1346).

${ }^{131}$ RG.17.6.1982, S. 17727.
} 
Bu anlamda otopsi , kuşkulu ölümlerde, gerçek ölüm nedeninin belirlenmesi ve bunun gibi suç delillerinin elde edilmesi amacıyla yetkili kişiler tarafından ceset üzerinde yapılır. Otopsi yapılması, kişinin sağlı̆̆ındaki ya da yakınlarının ölümden sonraki rızalarının varlığını gerektirmeyen kamu düzenini ilgilendiren bir işlemdir. ${ }^{122}$ Buna karşılık her hangi bir şekilde yasal zorunluluğun bulunmadığ durumlarda otopsi yapılması kişilik haklarına aykırılık oluşturur. ${ }^{123}$

Ancak bazı durumlarda kamu düzeni ve genel ahlak kurallarma aykırı olmamak üzere ceset, bazı hukuki işlemlerin konusunu oluşturabilir (2238 Sayılı Kanun). Özellikle cesedin gömülme yeri ve biçimine karar verilirken kamu düzeni ve Idare Hukuku kuralları göz önünde tutulmalıdır ${ }^{124}$. Bununla birlikte ceset uzerinde belirli tasarruf ve girişimlerde bulunmak üzere yapılacak işlem, parasal sonuç doğurmaya yönelikse geçersiz sayılmalıdır ${ }^{125}$. Ancak, modern eğilim ve gereksinimler göz önünde tutularak, bilime hizmet ya da başkalarına sağlık kazandırmak gibi "üstün bir amaca yönelik " işlemlerin hukuka aykırı sayılmaması gerektiği ögretide belirtilmiştir. ${ }^{126}$

Öğretide savunulan bu görüş, 2238 Sayılı Yasa ile dayanağını bulmuştur. Klasik kişilik hakkı görüşü, bir kişinin cesedi üzerinde tasarrufta bulunmasınt uygun bulmaz ${ }^{127}$. Buna karşıllk, modern eğilimlere uygun olarak, bilimsel amaçlarla ve üzerinde denemeler yapılmak, tıp alanında egitilenlere gösterilmek ya da başkalarının tedavisinde kullanılmak üzere kişi, cesedi üzerinde tasarruflarda bulunabilir .Bu tasarruf resmi ya da yazılı bir vasiyetname düzenlenerek olabileceği gibi iki tanık önünde açıklanan irade beyanı yoluyla da olabilir (2238 Say1lı Yasa md. 14/I).

Bir kişi sağlığında, kendisinden ölümünden sonra organ veya doku alınmasına karşı olduğunu belirtmişse organ ve dokusu alınamaz (md. 14/II'nin karşıt kavramından). Ancak kişi ölïmünden önce bu konuda her hangi bir tasarrufta bulunmamışsa yakınlarının izniyle ölüden organ ya da doku alınabilecektir (md. 14/I). Yasanın bu konudaki düzenlemesi şöyledir : "Bir kimse sağlığında vücudunun tamamını veya organ ve dokularını tedavi , teşhis ve bilimsel almaçlar için bıraktığını resmi veya yazılı bir vasiyetle belirtmemiş veya bu konudaki isteğini iki tanık huzurunda açıklamamış ise sırasıyla ölüm anında yanında bulunan eşi, reşit çocukları, ana veya babası

\footnotetext{
122 Bak. Arpacl. 129.

${ }^{123}$ Karş Özsunay (Hayat), 37, dn. 72.

${ }^{124} \mathrm{Dural} / \mathrm{Ögüz} \mathrm{(Dural),} 30$.

${ }^{125}$ Dural/Ö̆ğüz(Dural), 30; Öztan, 31; Ataay, 130; Ayiter, 143; Köprülü, 267; Zevkliler/Acabey/Gökyayla. 453

${ }^{326}$ Ataay, 129.

${ }^{127}$ Ataay. 130.
} 
veya kardeşlerinin birisinin; bunlar yoksa yanında bulunan her hangi birinin muvafakatiyle ölüden organ ve doku alınabilir."

Ögretide, ölünün yakınlarının izniyle cesetten organ ya da doku alınabilmesi hususundaki yasal dïzenlemenin yetersiz oldugu savunulmaktadır ${ }^{12 \%}$. Bu görüşte olanlara göre yakınlar bu karan oybirliğ̣ ile $^{129}$ ya da hiç olmazsa oy çokluğu ile vermelidirler ${ }^{13 !}$.

Fikrimce bu düzenlemenin temelinde yanlışlık vardır. Öncelikle 14. maddede getirilen hükümler birbiriyle çelişki içindedir. Gerçekten 2. fikradıı "Aksine bir vasiyet veya beyan yoksa, kornea gibi cesel üzerinde bir değişiklik yapmayan dokular alınabilir." 3. fıkrada "Ölü, sağ lığında kendisinden ölümünden sonra organ veya doku alınmasma karşı olduğunu belirtmemişse organ ve doku alınabilir." denilmekte 4. fikrada ise (Değişik: 21/1/1982-2594/1 md.)"Kaza veya doğal afetler sonucu vücudunen uğgradığ ağır harabiyet nedeniyle yaşamı sona ermiş olan bir kişinin yanında yukarıda sayılan kimseleri yoksa, sağlam doku ve organları, tıbbi ölüm halinin alınacak organlara bağlı olmadığı 11 maddede belirlenen hekimler kurulunun raporuyla belgelenmek kaydıyla, yaşamı organ ve doku nakline bağlı olan kişilere ve naklinde ivedilik ve tıbbi zorunluluk bulunan durumlarda vasiyet ve rıza aranmaksızın organ ve doku nakli yapılabilir. Bu hallerde, adli otopsi, bu işlemler tamamlandıktan sonra yapılır ve hekimler kurulunun raporu adli muayene ve otopsi tutanağına geçirilir ve evrakına eklenir. denilmektedir. Yine 5. fikrada "(Değişik: 21/1/1982- 2594/1 md.) Ayrıca vücudunu ölümünden sonra inceleme ve araştırma faaliyetlerinde faydalantlmak üzere vasiyet edenlerle yatakiı tedavi kurumlarında ölen veya bunların morglarma getirilen ve kimsenin sahip çıkmadığını ve adli kovuşturma ile ilgili olmayan cesetler aksine bir vasiyet olmadığı takdirde 6 aya kadar muhafaza edilmek ve bilimsel araştırma için kullanılmak üzere ilgili yüksek ögretim kurumlarına verilebilirler. Bu cesetlerin defin hususu dahil tabi olacakları işlemler Adalet, İçişleri, sağlık ve Sosyal Yardım Bakanlıklarınca bu Kanunun yayımı tarihinden itibaren 3 ay içinde çıkarlacak yönetmelikle belirlenir" hiikmü getirilmiştir ${ }^{131}$.

Bu düzenlemenin "üstün amaç ve değgerlere" hizmet ettiği . "ulvi” bir amacı olduğu ileri sürülemez. Gerçekten böyle bir düşünce olsayd 1 yasanın diğer hükümlerini de kapsaması gerekirdi. Böyle bir düşünce ile yapılması gereken ise "üstün amaç ve değerlerin" söz konusu olduğu her durundáa

\footnotetext{
12\% Zevklilcr/Acabey/Gökyayla, 453.

${ }^{124}$ Zevklıler/Acabcy/Gökyayla, 453; Dural/Öğüz(Dural). 26.

${ }^{1.3 t}$ Köprülüi, 275.

${ }^{131}$ Bu hususta kabul edilen modeller ve bu konudaki gِcniş açıklamalàr için bak. Akincı 124 vd.
} 
sahipli -sahipsiz ceset ayrımı yapılmaksızın bir düzenlemeye gidilmesidir. Bu da kişinin ölümden sonra ortaya çıkan cansız bedeninin, tedavi amaçlı olarak, özellikle yaşamı cesetten alınacak organlara bağlı kişilere aktarılması, kişinin sağlığında bunun aksine bir irade beyanında bulunmaması koşuluna bağlanabilir. ${ }^{132} \mathrm{Bu}$, hem bilim adına, hem insanlık adına yapılan bir davranış olarak nitelendirilebilir. Kişinin ölmeden önceki düşüncelerine değer verilmesinin kabul edilmesi halinde ise, her durumda kişinin bu konudaki olumlu düşünce ya da davranışının varlığı aranmalıdır. Kişinin ölümden önce olumlu ya da olumsuz bir davranış ya da düşüncesinin söz konusu olmaması halinde ise, öğretide ileri sürüldüğü gibi yakınlarının oybirliği ya da hiç olmazsa oy çokluğu ile verecekleri karar geçerli olmalıdır. ${ }^{133}$

\section{E- Ceset Üzerindeki Hakkın Korunması}

\section{1- Genel Olarak}

Yaşayan kişinin genel kişilik hakkı ve bundan türetilen özel kişilik haklarının korunmasının yanısıra vücut bütünlüğü, vücut işlevlerinin korunması kapsamlı ve mutlak bir şekilde korunması sağlanmışken (BK/OR md. 41/I, BGB $\S 823$ ), ${ }^{134}$ ölen insana ayrılan korumanın boyutu oldukça küçüktür. Cansız bedenin bütünlüğüne yönelik bir saldırı, vücut yaralama olayı kapsamında değil, en fazla ölen kişiye uyarlanmış kişilik hakkı kapsamında (ölü bakım hakkı) kapsamında değerlendirilmektedir (Karş.TCK md. 178). Bir "çerçeve hak" olarak kişilik hakkının ihlal edilmesi (beden bütünlügüüün ihlalinden farklı olarak), ancak içinde saldırı nedenini ve saldırının şiddetini de barındıran ${ }^{135}$ çok kapsamlı bir mal ve menfaat ölçüsüyle değerlendirmeye tabi tutulduğunda bir sonuç olarak kabul görürken; ${ }^{136}$ kişilik hakkının ön planda olduğu olaylarda sorumluluk smırı,

\footnotetext{
${ }^{132}$ Bu sontuç Avusturya Hukukunda kabul edilmiştì. Gerçekten, cesetten organ ve doku aktarılmasımı düzenleyen Krankenanstaltengesetz (KAG) $\$ 62$ a/l gereğince, cesetten organ alınınası , kişinin hayattaki iradesine ya dá ölümden sonra yakınlarının iznine tabi olmayıp, ancak ölmeden önceki kişinin iradesi dikkate alınır.

133 Zevkliler/Acabey/Gökyayla. 453.

1.34 "Yașam". "vücut", ve "sağlık" Alman Medeni Kanunu (BGB) $\$ 823 /$ de kesin olarak korumması gercken mal olarak belirtilmiştir. Karş BK md. 41/I. BGB $\$ 823$ 'de belirtilen bu durumlar ve BK md. 41 ile ilgisi için bkz. Atamer . $6 \mathrm{vdl}$.

135 Taupitz. 9. Ömeğin Bonn Eyalet Mahkemesi organ nakli için kullanılan bir organ ahımını "zarar vermenin objektif anlamı yaralama olayının gerçck sebebi tarafından hafifletilmektedir" gerckçesi ile ă̆ır kişilik hakkı iłláli olarak değerlendirmemiştir LG Bonn, JZ 1971, 56,61.

1.2. Taupitz. 9 .
} 
vücuda yönelik saldırılara oranla daha yüksektedir. ${ }^{137}$ Ancak dogmatik hukuksal çıkış noktasındaki bu farklılık, ölen kişinin mal ve menfaat ölçüsünü bizzat tayin etme hakkı ne oranda göz önünde bulundurulursa, uyumsuzlukların da o oranda azalmasını vesile olur. Uyumlu bir değerlendirmeye, hukuka uygun ahınmış vüicut parçalarının alınması değil; nasıl kullanıldığı göz önünde bulundurulduğunda ulaşılabilir. Burada. yaşayan insanta ilintili olarak, vücudun korunmasından çok genel kişilik hakkının korunması ön plandadır. ${ }^{138}$

Yaşayan bir insanda olduğu gibi ölmüş bir insanın medeni hukuk tarafından korunmasının hareket noktasını, bütün kişisel de ğerler üzerinde, kesin ve herkes için geçerli olarak korunan kişilik hakkı oluşturmaktadır. ${ }^{134}$

İster kişiliğin ölümden sonta sona ermesi nedeniyle bir an bile sürmeyeceği, ister kjşiliğe ilişkin en azından bir takım değerlerin bir süre için de olsa süreceği görüşü kabul edilsin, kişilik haklarına ölümden sonra yapılan saldırılara karşı koruma söz konusu olacaktır. Bu günkü pozitif hukuk düzenlememiz açısından, korumayı talep edecek olan (her iki görüş açısından da ortak olarak kabul edildiği gibi) yakınlardır.

Burada "yakın" kavramının ne olduğu konusu üzerinde durmakta da yarar vardır. Gerçekten böyle bir durumda kimin yakın akraba olarak kabul edilebileceği sorunludur. Yakınlık mirastaki sıraya göre değil y yakın olarak nitelendirilecek kişinin ölenle arasında var olan yakınlığa göre belirlenmelidir. ${ }^{100} \mathrm{Bu}$ durumda ölen kişiyle olan ruhsal yakınlığa önem verilmelidir; eğer bir uzak akraba ölen kişinin aynı zamanda bakıcılığını yapmışsa, bu kişi bu nedenle "ölüm sosyal yardımı" sorumlusu "en yakım akraba" olarak görülebilir. Ölen kişinin kendi kendine karar verme yetkisinin arttırılması "hasta vasiyetnamesinin" hukuksal anlamda tanıması veya "sağlıkla ilgili işlerde tam yetkili kılınması" ile de ulaşılabilit." ESCHER"e göre de yakın kavramı nispîdir. Kural olarak kişinin altsoyu, akrabaları, kardeşleri ve eşi bu kavrama dahildir. Uzak akrabalarda ise aradaki somut ilişkiler belirleyici olacaktır. Aynı zamanda akraba olmayan bir üçüncü kişi de yakın sayılabilir. Örneğin arkadaş ya đa koruma altında bulundurulan kişi . Bu duruma kız ya da erkek arkadaşı ile bir evi birlikte paylaşan kişiler de girer. ${ }^{142}$ Bu durumda yakmlar,ölen kişi ile ilgili, ölenin

\footnotetext{
${ }^{137}$ Ölii. ccza hukuku açısından, fiziksel ölümün gerçekleşmesinden itibaren bir süre dahaolağan koşullar altında defne kadar- kişiye sıkı sıkı bağlı hakların sahibidir. (BGE II8 IV 319).

${ }^{138}$ Taupitz. 9 .

139 Jäggi, 149a.

${ }^{1+0}$ Özsunay, 212; Dural/Öz̆ì2, 26; Oğuzman/Seliçi/Oktay, 16, 17; Eggger. Art 31, N. 16.

14) Taupitz. s. 8. dn 14.

1.2 Escher, Art. 477. N.I5
} 
lehine bir koruma zorunluluğunu da içeren, kişilik hakkının kullanıcıları durumuna gelirler. ${ }^{143}$ Bu kişilik hakkının uygulaması, ölen kişinin isteği ve düşünüş biçimine uygun olmalıdır; sıralama açısından karar vericiler içerisinde yine de ölen kişiye öncelik verilir ${ }^{144}$. Özellikle ölen kişinin yaşadı̆̆ı dönemde ölümünden sonra cesedinin nasıl kullanılacağı ile ilgili kesin bir şekilde reddettiği veya kabul ettiği konular hakkında yakınlarının itiraz hakkı yoktur ${ }^{145}$. Sadece yakıların ölen kişinin tahminen nasıl bir karar verebileceği konusunda bir fikirleri olmaması durumunda onların - bu durumda yine de ölen kişinin menfaati gözetilir - kararma öncelik verilir. ${ }^{146}$ Ölenin onur ya da saygınlığına saldırıldığı, giz alanına girildiği ya da istençlerine aykırı olarak açıł̆a çıkarıldığı durumlarda, yakınların, kişilik haklarını koruyucu hükümlere dayanarak dava açmaları söz konusu olacaktır (MK md. $25^{147}$ BK md. 49). ${ }^{148}$ Buna karşıllı tazminat davası açması bu hakların korunmasının niteliği ile baðdaşmaz ${ }^{149}$.

\section{2- Ceset Üzerindeki Hakkı Koruyucu Davalar}

Medeni Kanunun 24. Maddesi 12.5. 1988 gün ve 19812 Sayll Resmi Gazete'de yayınlanarak yürürlüğe giren 3044 Sayılı Yasa ile değiştirilmiştir. Ayrıca bu yasa ile 24a maddesi eklenmiştir. Yapilan bu düzenlemeyle, eski hükme oranla daha geniş bir biçimde, rızaya aykırı olarak yapılan saldırılara karşı kişilik korunmaktadır. Ancak bu korumayı tamamlayan ve söz konusu 3044 sayılı Yasa ile de giştirilen Borçlar Kanununun 49. maddesinin de birlikte ele alınması gerekmektedir. Bu hükümler çerçevesinde, kişiliğe yönelik bir saldırı olduğunda; durdurma (men); önleme; tespit davası ile vekaletsiz işgörmeden kaynaklanan davalar açılabilecektir. Bu davaların açılabilmesi için saldırının hukuka aykırılı̆̆ını kaldırmayan saldırının durdurulması (men), önlenmesi ,saptanması (tespit) davaları açılabilecektir. Ayrıca bu davalar sonucu verilecek kararlarn etkili biçimde yerine

\footnotetext{
${ }^{1+3}$ Akrabalarun ölen kişinin bizzat karar verme hakkının gerisinde kalan temel hakları için bkz. Schrnidt-Didczuhn, 264.266.

${ }^{144}$ Schimid-Didchzuhn, 264. 266.

${ }^{1+5}$ Deutsch, 261; Taupitz, 8

${ }^{140} \mathrm{Bu}$ durumda akrabaiar ölen kişinin sadece tahmini veya gerçek istekleri hakkında bilgi alınabilecek kişiler değjllerdir. Taupitz, 8: Deutsch, 262

${ }_{1+7}$ Yeni Medeni Kanun ile 24a Maddesi'nin yerine 25. madde koyulmuş ve İsviçre'de 1985 yılında yapılan deģişikłikle getirilen 28a maddesi aynen hükme alınmıştır. (1998 Tarihli) Türk Medeni Kanunu Tasarısı, Madde Gerekçeleri , 6-7.

${ }^{1+*}$ Kişiliğin korunmasına iłjşkin düzenlemeler bunlardan ibaret değildic. Bunların yanısıra başta Anayasa olmak üzere (md. 12, 17, 22, 48); Ceza Kanuna (md. 17, 174, 179. 181 -186, 194, 197-199. 201. 448 vd.) ; Fikir ve Sanat Eserleri Kanunu. Basin Kanunu. TRT Kanunu. 2238 Sayılı Kanun vb. yanısıra Medeni Kanunun 26,I21, 158, 174, hükümleri ile Borçlar Kanununun 45 ve 48 , maddelerinde de kişiliğin korunmassına ilişkin hükümlere rastlanmaktadır

${ }^{1+10}$ Bak. Öztan, 25.
} 
getirilmesini sağlamak amacıyla, mahkemeden tedbir nitelikli bazı istemlerde ${ }^{15(t)}$ de bulunulabilecektir. Bununla birlikte yakınların, saldırının yarattığı sonuçlara yönelik olarak da vekaletsiz iş görmeden kaynaklanan dava ile maddi ve manevi giderim (tazminat) davalarımı açma hak ları vardır (MK. Md. 25, BK. md. 49). Kişiliğin korunmasına ilişkin bu davalarda yetkili mahkeme davacının ya da davalının ikametgâhı mahkemesidir (MK. md. $25 / \mathrm{V})$ ).

\section{a- Durdurma Davasi}

$\mathrm{Bu}$ dava, kişisel varlıklardan lier hangi birine yapılan saldırmın başlaması ya da devam ediyor olması halinde açılır; ${ }^{151}$ davanın açılması için saldırganın kusuru aranmaz; saldırının haksız olması yeterlidir. ${ }^{152}$ Ayrıca, saldırı nedeniyle mağdurun her hangi bir zarar görmesi koşulu da bu ıür davalar için aranmış değildir. ${ }^{153}$

Durdurma davası saldın sürdügü müddetçe açılabilitit ve bu süre içinde zamanaşımına da uğramaz. ${ }^{15 j}$

\section{b- Önleme Davası}

Bı dava, henijz gerçekleşmemiş, ancak gerçekleşme tehlikesi gösteren kişilik hakkına yönelik saldırı emarelerine karşı açılır. ${ }^{156}$ "Tehlikenin" yakın ve ciơdi olması, esaslı bir endişe yaratması aranır. ${ }^{157}$ Böylece gerçekleşmesi olast saldırının, henüz etkilerini doğurmadan önlenmesi amaçlanır. Bu dava da da, saldırı tehlikesini oluşturan durumlarda, bu davranışm haksızlığı tek başına yeterlidir; kusur aranmaz. ${ }^{158}$

\footnotetext{
1:a1 Kars Jäggi. 252a.

13̄ Dural/Ǫ̈üz(Dural). 152; Tekinay, 268; Zcvkliler/Acabey/Gökyayla, 526; Oztall. 152; Arpacı. 151: Akipek/Akıntürk, 157; Egger. Art 28, N. 78; Jäggi. I75a.183a.

152Zevkliler/Acabey/Gökyayla, 526: Dural/Öğüz(Dural). 52: Tekinay, 269: 153: Arpacı, 151: Egger. Art.28. N. 79; Akipck/Akıntürk, 162;

15. Zevkliler/Acibhey/Gökyılylo, 527; Dural/Ögüzu(Dural), 152. Karş. Akipek/Akı)türk, 157: Öztan, 153; Esger. Art.28. N. 79.

Ist Dural/Ǫ̈ï\% (Dural), 152. Karş. Öztan, 153; Akipck/Akıntürk. I56: Zevkliler/Acibey/Gïkyayla, 527; Egger, Art, 28, N. 79; BGE 126 III 16I.

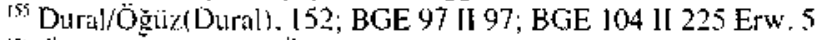

15. Ötan, 153; Dural/Ögliz(Dural), 152;Akipck/Akıntürk, s158; Zevkliler/Acabey/Gökyayla. 528: Egger. Art, 28, N, 82.

${ }^{157}$ Dural/Ögü (Dural). 152; Oztan, 154; Egger. Art. 28. N. 82. Karş ZGB Art. 28a.

15x Öztan. 154: Dural/Öğuz(Dural), 153: Zevkliler/Acabey/Göhyayla. 529: Karș. Egger. Art. 28. N. 82 .
} 


\section{c- Tespit Davası}

MK md. $25^{\prime}$ de düzenlenmiş diğer bir dava da, hukuka aykırılığın tespitine yönelik genel tespit davasının özel olarak kişiliğe saldırı haline ilişkin tespit davasıdır. ${ }^{159}$ Bu dava ile kişilik haklarına karşı gerçekleştirilmiş ve etkileri hala sürmekte olan davranışın hukuka aykırılığının saptanması amaçlanır. Bu davada da kusur anmadığı gibi, bir zarar ortaya çıkmış olması da aranmaz. ${ }^{100}$ Mahkeme tarafından verilen kararın, gerektiğinde yayınlanmasına ya da u̇çüncü kişilere bildirilmesine karar verilmesi istenebilir (MK md. 25/II).

\section{d- Vekaletsiz İş Görme Davası İle Maddi Ve Manevi Tazminat Davaları}

Kural olarak ölenin onur ya da saygınlığına saldırıldığı, giz alanına girildiği ya da istençlerine aykırı olarak açı̆̆a çıkarıldı̆̆ı durumlarda, yakmların, kişilik haklarını koruyucu hükümlere dayanarak yukarıda sayılan davaları açmaları söz konusu olacaktır. Ancak kişilik haklarının ihlalinden dolayı, kişilik hakları yakınları aracılığıyla korunan ölünün manevi ya da maddi zarara uğradiğından ya da elde "tecavüzden elde edilen kazançları vekaletsiz iş görme hükümleri uyarınca talep etme hakkı"nın olmasından söz edilmesi eşyanın doğasına aykırıdır. Bu sebeple, bu tür davalar ancak aynı zamanda yakınların da kişilik haklarının haksız biçimde ihlal edilmesi hallerinde söz konusu olabilecektir. Bu durumda saldırının haksız bir fiil oluşturmadığı ve davacının mal varlığında bir eksilmeye neden olmadığı için davalının sebepsiz zenginleşmeden söz edemeyeceği hallerde vekaletsiz iş görme özellikle de gerçek olmayan vekaletsiz iş görme hükümleri işlerlik kazanabilecektir (BK md. 410 vd.). ${ }^{161}$ Bu dava mağdurun elde etmek istemediği ya da elde edemeyeceği bir kazancın saldırıda bulunan kişinin

\footnotetext{
${ }^{159}$ Dural/Öğüz(Dural), 154; Öztan, 154; Zevkliler/Acabey/Gökyayla, 530. Bak. Egger, Art. 28. Nr. 76 vd. Akipek/Akıntürk. 158 vd. BGE I22 III 449; BGE 120 II 371: BGE 113 II 13; 97 II 97 . Tekinay'a göre genel tespit davalarından farklı olarak burada bir tatmin amacı vardır (Tekinay. 273).

16) Dural/Öğüz(Dural), 155; Akipek/Akıntürk, 159; Öztan, 154. Tekinay, tespit davası açabilmek için saldırının sona ermesi gereğinin anlamsız olduğunu belirtnektedir. (Tekinay, 274, aynı fikire Arpacı, 161). Oysa saldırının sürmesi ve ya da ileride doğmasının beklenmesi hallerinde başka dava yollarł vardır (Öztan, 154).

161 Tekinay, 275. Öğretide bu durumda gerçek olmayan vekaletsiz iş görme (karş. Öztan, 162.Zevkliler/Acabey/Gökyayla, 550; Arpacı, 162, Bak. Hatemi, 95.) ve sebepsiz zenginleşme hükümlerinden yararlanılabileceği (Öztan. 162; Zevkliler/Acabey/Gökyayla, 550) düşünceleri vardır.
} 
yanina kalmamast amacina hizmet eder. ${ }^{162}$ Bu dava ayn zamanda maddi ya da manevi tazminat davaları ile birlikte de açılabilir. ${ }^{163}$

Bu çerçevede yine kişilik hakları ihlal edilen yakınlar, saldırı sonucu uğradı̆̆ 25/III).Tazminat davası açabilmek için kişilik haklarının hukuka aykırı olarak ihlal eden bir davranış. kusur ve davranışla zarar arasında illiyet bağı gereklidir. ${ }^{16 t}$ Tazminat talebinde bulunmanın ön koşulu mutlaka bir zararın varlığıdır. Zarar sözcüğö hukukumuzda dar ve geniş olmak üzere iki anlamda kullanılmaktadır. ${ }^{165}$ Zarar kavramı kural olarak dar anlamda zarara (buna madđi zarar da denilebilir) ${ }^{166}$ karşllık gelir. Dar anlamda zarar ise malvaslığında oluşan eksilme (damnum emergens) ya da artmanın önlenmesi (Iucrum cessans) olarak ortaya çıkan malvarlığı zararıdır (Vermögenschaden). Maddi zararm karşıtı ise manevi zarardır ${ }^{167}$ (immateriler Schaden). Maddi zarar malvarlsksal değerlerin ihlali sonucunda meydana gelirken, manevi zarar kişilik hakkmın koruma kapsamına giren değerlerin ihlalinden meydana gelen zarar olarak nitelendirilir. Geniş anlamda zarar ise bunların hepsini de birden kapsayacak şekikle kullanılır. ${ }^{10 \%}$ Böylece geniş anlamda zarar, hukuken korunan maddi ve manevi varlıkların, bunlara yapılan bir saldırının (ihlalin) gerçekleşmesinden önce ve sonraki durumları arasındaki fark olarak tanmlanır. ${ }^{169}$

Bu çerçevede kişilik hakkının ihlali nedeniyle tazminat istenebileceği özel olarak düzenlenmiş bir hükmün (MK md. 26,121, 158, 174: BK, md. $45,46.48 /$, TTK 58) ya da bunların kapsamı dışında kalan durumlarda

\footnotetext{
\$62 Bak. Dural/Öğüz (Dural), 155.

16i Dural/Ö̆ğuz (Dural), 156. Aksi görüşte, Arpacı, 162.

Irt Oztan, 15\%; Zcvkliler/Acabey/Gökyayla. 532; Akipek/Akıntürk, 164; Arpacı, kusursuz. sorumlulukla ilgili hükümler nedeniyle kusurun aranmayacağ hallere dikkat çekmektedir. (Arpaci. 153).

ins Tandoğan, 63.

Ioth Tandoğan. 63.

167 "Borçlar Kanununun 47. maddesi hïkmüne göre bir hahimin özel halleri gözöntinde tutarak manevi zarar adı ile hak sahibine verilmesine karar vereceği bir para tutarr adalete uygun olmalıdır. Hükmedilecek bu para - zarara uğrayanda manevi huzuru doğurmayı gerçcklcştirecek tazminata benzer bir fonksiyonu olan oz.gün bir nitclik tuşır. Bir ceza olmadı ̆̆ı gibi mamelek hukukna ilişkin zararın karşılanması da amaç edinmemiștir. O haldo bu tazminatın sınırı onun amacına göre belirlenmelidir. Takdir edilecek miktatı meveut halde elde cdilnıck istenilen tatmin duygusunun etkisine ulasmak için gerekli olan kadar olmalıdır." Y. 4. HD. E. 1996/I3717, K. 1997/3157 T. 27.3.1997 (Yasa Hukuk DergisiY.20, C.16. S. 185. s. 529). Ayn anlannda Y. 4. HD E. 1996/7573, K. 1996/10291, T. 21.10.1997 (Yas; Hukuk Dergisi. Y. 19.C. 15, S. 181, s.2017).

tthi Bkz. Hatemi. 44 vil: Keller. 39 vd.

Int Tandoğan, Mesiuliyet. 63.
} 
genel hükümlere (BK md. 41,49,96) göre tazminat istenebilecektir. ${ }^{170}$ Tazminatın miktarmı hakim belirleyecektir (BK md. 43). Bunun yanında manevi tazminatın belirlenmesiyle ilgili olarak, BK md. 49/II' deki hüküm gereğince"hakim, manevi tazminatın miktarını tayin ederken, tarafların sıfatını, işgal ettikleri makamı ve diğer sosyal ve ekonomik durumlarını da dikkate alı". ${ }^{71}$

\section{SONUÇ}

Ölümün belirlenmesi hususundaki kıstaslar "beyinsel ölüm" anlayışı üzerinde yoğunlaşmaktadır. Ancak tıp biliminin sürekli geliştiği günümizzde, sabit kıstaslara bağlı kalınması ve hukuksal düzenlemenin buna bağlı olarak yapılması istenmeyen sonuçlar doğurabilir. Bu yüzden insanın öldüğ̈̈̈ne dair tüm kușkuların bertaraf edilmediği bir anlayışı hukuk düzeni korumaz. Bu konuda özellikle tıp biliminin gelişmelerine hareket alanı sağlayacak ve ölüm anının belirlenmesi hususunu tıp bilimine bırakacak dïzenlemeler yerinde olarak değerlendirilir.

Cesedin bir mal olmadı̆̆ı, günümüzde kabul edilmiştir.Ceset üzerinde kişilik haklarından kaynaklanan koruma söz konusudur. Bu kişilik hakkı ölenin kişilik hakkının uzantıları ya da yakınlarının kişilik hakkı olarak ortaya çıkar. Günümüzün değişen koşullarında cesedin -belli sınırlar içindehukuksal işlemlerin konusu olacağ 1 kabul edilmektedir. Ceset üzerinde tasarrufa izin veren tek yasal düzenlememiz 2238 Sayılı Yasa'dır. Ancak bu Yasa getirdiği hükümlerle "düzenleme"den çok karışıklı̆̆a sebep olmaktadır. Bu yüzden organ aktarmaları ile ilgili yeni ve çağdaş bir yasanın getirilmesi yerinde olur. Bu anlamda olmak üzere, "bedeni harabiyete uğramış kişiler" ve sahipli-sahipsiz ceset kavramlarının kişilik haklarına uygun bir düzenleme ile yeniden değerlendirilmesinin yerinde olacağı görïşündeyiz.

\footnotetext{
${ }^{170}$ Dural/Öğüz (Dural), 157. 158; Arpacı, 153, Bu durumda, kusurun kanıtlanmas1. zamanaşımı gibi darumlar her bir hüikmủn kendi koşulları üzerinde değerlendirilmelidir (Arpact, 153). Öztan, manevi tazminat açısındanyasakoyucanun iradesinin BK md. 47'de kusur aramadığı biçiminde yorumlanması dúşüncesindedir ( 161).

121 Bu hüküm öğretide çok tartışılmış ve eleştirilmiştir. Bak. Dural/Öğüz(Dural)/Ögüz, 159; Arpacs, 156; Tekinay, 272,"takdir edilen maddi ve manevi ödence tarafların sosyal durumı.....ile uyumlu bulunmamaktadı" Y. 2. HD, E. 1995/7033, K. 1995/7919. T. 6.7.1995 (Yasa Hukuk Dergisi. Y. 19. C. 15, S.170, s. 96)
} 


\section{BİBLIYYOGRAFYA}

Akıncı: Türk Özel Hukukunda İnsan Kökenli Biyolojik Madde (OrganDoku) Nakli Kavjamı ve Bundan Doğan Hukuki Sonuçlar, Ankála 1996

Akipek/Akıntürk: Türk Medeni Hukuku, Birinci Cilt-İkinci Cüz, Şahsm Hukuku, Ankara 1996

Ataay: Şahıslar Hukuku, Birinci Yarım, Giriş-Hakiki Şahıslar, 3. Baııı, İstanbul 1978.

Ataay:"Vücud (Beden) Üzerindeki Hak". Mukayeseli Hukuk Araştırmaları Dergisi, 1996 Y. 20,. s. 25-28.(Kıs. Ataay, MHAD)

Atabek:"Hastanelerin Sortumluluğu", İBD,C.60, S. 10-11-12, s. 61.3 vd.

Atamer: Haksız Fiillerden Doğan Sorumluluğun Sınırlandırılması, İstanbul 1996.

Ayiter (Organ):"Organtransplantation als privatrechtliches Problem", Ankara Hukuk Fakültesi Mecmuası, Y.1975, C.XXXII, s.173vd.

Ayiter:"Sahsiyet Haklart Açisındant Organ Nakli", AHFM, Y.1968.C.XXXV, s.137-144.

Bayraktar: Hekimin Tedavi Nedeniyle Sorumluluğu, İstanbul 1972.

Bilge: Hukuk Başlangıcı, Hukukun Temel Kavram ve Kurunları, Ankara 2001.

Bilgin: Hayat İçin Elzem Organların Naklinde Başlıca Hukuki Problemler ve Çözüm Yolları, İBD Eylül-Ekim 1968 Eki-1, İstanbul 1968.

Deutsch: Ärtzrecht und Arzneimittelrecht, Berlin 1991

Dural/Ögüuz(Dural): Kişiler Hukuku, Birinci Cilt ,Gerçek Kişiler.İkinci Cilt, Tüzel Kişiler, İstanbul 2001.

Egger: Kommentar zum schweizerischen Zivilgesetsbuch, I. Band, Einleitung und Personenrecht, Unveränderter Nachdruck 1978 der zweiten Umgearbeiteten Aufl. 1930, Zürich 1930.

Erdoğan:"Avrupa Birliği Anayatsalarnda Devletin Temel Nitelikleri", Liberal Düşünce. Yaz 2001, N. 23, s. 5 vd.

Escher/Escher: Kommentar zum schweizerischen Zivilgesetzbuch, III. Band. 2. Abteilung. Der Erbgang, 3. Auflage, Zürich 1960.

Geilen:"Medizinischer Fortschritt und juristischer Todesbegriff", Festschrift für Ernst Heinitz. Berlin 1972, 373 vd.. 383 vd $303 \mathrm{vd}$.

Grossen:Das Recht der Einzelpersonen. Schweizerisches Privatrecht, 
Giiner: "Hukuksal Yönden Organ Aktarması ve Konuya Illişkin Yargitay Göriuşü̆", AD, Y. 66. S. 5/6, s. 587 vd.

Güriz:Hukuk Başlangıcı, Gözden Geçirilmiş, Değiştirilmiş ve Genişletilmiş 8. Bask1, Ankara 2001.

Gürkan:"Kişilik Kavrammın Evrimi", Hamide Topçuoğluna Armağan, Ankara 1995, s. $39 \mathrm{vd}$.

Gürsoy/Eren/Cansel:Türk Eşya Hukuku, Ankara 1984.

Hatemi:Kişiler Hukuku Dersleri, İstanbul 2001

Hatemi (Borçlar): Kocayusufpaşaoğlu/Hatemi/Serozan/Arpacı, Borçlar Hukuku, Sözleşme-Dışı Sorumluluk Hukuku, İstanbul 1997.

Hatemi/Serozan/Arpacı: Eşya Hukuku, İstanbul 1994.

Hinderling :"Organ Aktarmasinın Ortaya Çıkardığ Hukuk Sorunlart" (Çev.:Erdener Yurtcan) Mukayeseli Hukuk Araştırmaları Dergisi,1969, Y.3. S.5, s.419-427.

Huber, Erläuterungen zum Vorentwurf eines schweizerischen Zivilgesetzbuches, 2. Aufl., 1. Band.

Jäggi Fragen des Privatrechtlichen Schutz der Persönlichkeit, ZSR 79 II s. 137a vd.

Jellinek: Die sozialethische Bedeutung von Recht, Unrecht und Strafe, Berlin 1908.

Karahasan:Tazminat Davaları , İstanbul 1976.

Kaser: Römisches Privatrecht, München 1981.

Keller: Haftpflicht im Privatrecht, Bern 1979

Köprülü: Medeni Hukuk, Genel Prensipler-Kişinin Hukuku, 2. Bası, İstanbul 1984.

Luternauer:Die ärztliche Pflicht zur Lebenserhaltung unter besonderer Berücksichtigung der Frage des Hirntodes, Diss. Basel 1971.

Merz:Anfang und Ende der Perönlichkeit, ZSR 76,s. 321 vd.

Müller:Recht auf Leben, persönliche Freiheit und das Problem der Organtransplantation, ZSR 90/1971

Oğuzman/Seliçi/Oktay: Kişiler Hukuku (Gerçek ve Tüzel Kişiler), İstanbul 1999

Özsunay: Gerçek Kişilerin Hukuki Durumu, İstanbul 1979.

Özsunay(Hayat)"Hayatın Başlangtct ve Sonuna Ilişkin En Önemli Hukuksal Sorunlar", Bülent Davran'a Armağan, 1998, s.2 vd.

Öztan: Şahsın Hukuku, Hakiki Şahıslar, Ankara 2001. 
Schimid-Didchzuhn:"Transplantationsmedizin in Ost ind west im Spiegel des Grundgezets" ZRP 1991.s. 264 vd.

Schultz:Organtransplantation, Schweizerische Ärztezeitung $\mathrm{Nr}$. 33/1968, s.. 881.

Serozan:"Kişilik Hakkının Korunmasıyla Ilgili Bazl Dïşiinceler", Mukayeseli Hukuk Araştırmaları Dergisi,1977, Y.11, S. 14, s. 93 vd.

Strartenwerth:"Zum juristischen Begriff des Todes", Festschrift für Karl Engisch, Frankfurt 1969, s. 528 vd.

Tandoğan:Mes'uliyet Hukuku, Ankara 1963.

Taupitz:Das Recht im Tod: Freie Verfügbarkeit der Leiche? Rechtliche und ethische Probleme der Nutzung des Körpers Verstorbener, Dortmund 1996.

Tekinay Medeni Hukukun Genel Esasları ve Gerçek Kişiler Hukuku, Istanbul 1992.

Toroslu:"Organ Aktarma ve Cezai Sorumluluk", AÜHFD, 1978, C. XXXV.S.1-4, s.91-118.

Umar:Hukuk Başlangıcı, İzmir 1997.

Velidedeoğlu:Türk Medeni Hukuku, Clilt: 1-Cüz:2, Şahsın Hukuku, İstanbul 1956.

Wolf/Naujoks:Anfang und Ende der Rechtsfähigkeit des Menschen, Franfurt a. M 1955.

ZevkliJer/Acabey/Gökyayla: Zevkliler Medeni Hukuk, Giriş Başlangıç Hükümleri. Kişiler Hukuku, Aile Hukuku, Ankara 1999. 


\section{Kisaltmalar}

Art. : Artikel

Aufl. : Auflage (Bask1)

AÜHFM : Ankara Üniversitesi Hukuk Fakültesi Mecmuası

$\mathrm{AD} \quad$ : Adalet Dergisi

Bak. : Bakınız

BGB : Bürgerliches Gesetzbuch

BGE : Bundesgerichtsentscheidungen.

$\mathrm{BGH}$ : Bundesgerichtshof

BK : Borçlar Kanunu

C : Cilt

CK : Ceza Kanunun

CMUK : Ceza Muhakemeleri Usulü Kanunu

çev. : Çeviren

dn : Dipnotu eMK 743 Sayll Türk Kanunu Medenisi (eski Medeni Kanun)

Erw. : Erwägungen

IBD : Istanbul Barosu Dergisi

İKID : İlmi ve Kazai İçtihatlar Dergisi

IUHFM : Istanbul Üniversitesi Hukuk Fakültesi Mecmuası

K : Karar

LG : Landesgericht

md. : Madde

MK : 4721 Sayılı Türk Medeni Kanunu

$\mathrm{N} \quad$ : Numara

NJW : Neue Juristischen Wochenschrift

OR : Obigationenrecht (Isviçre Borçlar Kanunu)

RG : Resmi Gazete

s. : Sayfa

S. : Sayı

SZR : Zeitschrift für schweizerisches Recht

TTK : Türk Ticaret Kanunu

Y : Yil

YHD : Yargitay Hukuk Dairesi

ZGB : Zivilgesetzbuch 